\title{
INTERVERTEBRAL DISC DECELLULARISATION: PROGRESS AND CHALLENGES
}

\author{
M.F. Fiordalisi ${ }^{1,2,3}$, A.J. Silva ${ }^{1,2}$, M. Barbosa ${ }^{1,2,3}$, R.M. Gonçalves ${ }^{1,2,3}$ and J. Caldeira ${ }^{1,2, *}$ \\ 1 i3S - Instituto de Investigação e Inovação em Saúde, Universidade do Porto, Porto, Portugal \\ ${ }^{2}$ INEB - Instituto de Engenharia Biomédica, Universidade do Porto, Porto, Portugal \\ ${ }^{3}$ ICBAS - Instituto de Ciências Biomédicas Abel Salazar, Universidade do Porto, Porto, Portugal
}

\begin{abstract}
Intervertebral disc (IVD) degeneration and the consequent low-back pain (LBP) affect over $80 \%$ of people in western societies, constituting a tremendous socio-economic burden worldwide and largely impairing patients' life quality. Extracellular matrix (ECM)-based scaffolds, derived from decellularised tissues, are being increasingly explored in regenerative medicine for tissue repair. Decellularisation plays an essential role for host cells and antigen removal, while maintaining native microenvironmental signals, including ECM structure, composition and mechanical properties, which are essential for driving tissue regeneration.

With the lack of clinical solutions for IVD repair/regeneration, implantation of decellularised IVD tissues has been explored to halt and/or revert the degenerative cascade and the associated LBP symptoms. Over the last few years, several researchers have focused on the optimisation of IVD decellularisation methods, combining physical, chemical and enzymatic treatments, in order to successfully develop a cell-free matrix. Recellularisation of IVD-based scaffolds with different cell types has been attempted and numerous methods have been explored to address proper IVD regeneration.

Herein, the advances in IVD decellularisation methods, sterilisation procedures, repopulation and biocompatibility tests are reviewed. Additionally, the importance of the donor profile for therapeutic success is also addressed. Finally, the perspectives and major hurdles for clinical use of the decellularised ECM-based biomaterials for IVD are discussed. The studies reviewed support the notion that tissue-engineering-based strategies resorting to decellularised IVD may represent a major advancement in the treatment of disc degeneration and consequent LBP.
\end{abstract}

Keywords: Decellularisation, recellularisation, intervertebral disc, tissue engineering.

*Address for correspondence: Joana Caldeira, R. Alfredo Allen 208, 4200-135 Porto, Portugal. Telephone number: +351 226074900 Email address: joana.caldeira@i3s.up.pt

Copyright policy: This article is distributed in accordance with Creative Commons Attribution Licence (http://creativecommons.org/licenses/by-sa/4.0/).

\begin{tabular}{llll}
\hline & List of Abbreviations & COL5A1 & collagen type V alpha 1 chain \\
& & DAF-G & decellularised AF-based hydrogel \\
ACAN & aggrecan & DAPI & 4', 6-diamidino-2-phenylindole \\
ADSCs & adipose-derived stem cells & DMMB & 1,9-dimethylmethylene blue \\
AF & annulus fibrosus & DMEM & Dulbecco's modified Eagle medium \\
AMSCs & amniotic stem cells & dsDNA & double-stranded DNA \\
APR & aprotinin & ECM & extracellular matrix \\
bFGF & basic fibroblast growth factor & EDTA & ethylenediaminetetraacetic acid \\
BM-MSCs & bone-marrow-derived mesenchymal & FBLN1 & fibulin-1 \\
& stem cells & FBS & foetal bovine serum \\
BSA & bovine serum albumin & FCT & Portuguese Foundation for Science \\
Ca12 & carbonic anhydrase XII & & and Technology \\
CCK8 & cell counting kit 8 & FDA & Food and Drug Administration \\
CD & ctuster of differentiation & Foxf1 & forkhead box F1 \\
Col1 & collagen type 1 & g-DAF-G & genipin-crosslinked DAF-G \\
Col2 & collagen type 2 & GAG & glycosaminoglycan \\
galactose-a-1,3-galactose
\end{tabular}




$\begin{array}{ll}\text { Gdf10 } & \text { growth differentiation factor } 10 \\ \text { H\&E } & \text { Hematoxylin \& Eosin } \\ \text { HYP } & \text { hydroxyproline } \\ \text { Ibsp } & \text { integrin-binding sialoprotein } \\ \text { IF } & \text { immunofluorescence } \\ \text { IHC } & \text { immonohystochemistry } \\ \text { IVD } & \text { intervertebral disc } \\ \text { K19 } & \text { keratin 19 } \\ \text { Krt19 } & \text { keratin 19 } \\ \text { LBP } & \text { low-back pain } \\ \text { MAC387 } & \text { macrophage monoclonal antibody } \\ & \text { clone 387 } \\ \text { MHC } & \text { major histocompatibility complex } \\ \text { Mmp13 } & \text { matrix metalloproteinase 13 } \\ \text { MSCs } & \text { mesenchymal stem/stromal cells } \\ \text { Ncam1 } & \text { neural cell adhesion molecule 1 } \\ \text { NP } & \text { nucleus pulposus } \\ \text { NPC } & \text { NP cells } \\ \text { Pax1 } & \text { paired box 1 } \\ \text { PEEK } & \text { polyetheretherketone } \\ \text { PKH26 } & \text { Paul Karl Horan 26 } \\ \text { RT } & \text { room temperature } \\ \text { SB } & \text { sulphobetaine } \\ \text { SDC } & \text { sodium deoxycholate } \\ \text { SDS } & \text { sodium dodecyl sulphate } \\ \text { SOX9 } & \text { SRY-box transcription factor } 9 \\ \text { TGF- } \beta & \text { transforming growth factor beta } \\ \text { TGF- } \beta \text { R } & \text { TGF- } \beta \text { receptor } \\ \text { TIMP } & \text { TIMP metallopeptidase inhibitor } \\ \text { TNMD } & \text { tenomodulin } \\ & \end{array}$

\section{IVD degeneration and LBP}

The human spine contains 24 IVDs localised between the vertebrae (Anderson and Tannoury, 2005) providing flexion, extension and rotation during daily activities (Tomaszewski et al., 2015). The IVD is composed of an external region, called AF, an internal region, named NP, and the endplates that enclose the disc (Fig. 1) (Tomaszewski et al., 2015). The AF, formed by 15-25 concentric lamellae that resist tensile stress (Colombier et al., 2014), is constituted mostly by Col1 (Oegema, 1993). In turn, the hydrogel-like NP is mainly composed of water, proteoglycans (Galbusera et al., 2014; Iatridis et al., 2007), Col2 (Urban and Roberts, 2003; Whatley and Wen, 2012) and elastin (Galbusera et al., 2014; White and Panjabi, 1990). Due to this composition, it supports the high compressive loads generated during daily activity (Mwale et al., 2004; Urban and Roberts, 2003; Whatley and Wen, 2012). Finally, the endplates, consist of hyaline cartilage (Raj, 2008; Tomaszewski et al., 2015) and control the diffusion of solutes and water (Tomaszewski et al., 2015). The disc ECM comprises different molecules that are crucial for tissue function (cellular support, proliferation, survival, morphogenesis, differentiation and signal transduction, among others), as reviewed elsewhere (Molinos et al., 2015; Newell et al., 2017).

Degeneration of the IVD is one of the most frequent causes of LBP (Vos et al., 2012; Waddell, 1996) and occurs with ageing. Disc degeneration is characterised by morphological modifications (e.g. collapse of intervertebral space, loss of hydration, sclerosis of endplate and osteophyte formation) that affect disc biomechanics, particularly spine flexibility (Galbusera et al., 2014). As a result of degeneration, the IVD can start to bulge leading to disc herniation, with associated radiculopathy and discogenic pain (Martin et al., 2002). Moreover, cellular and biochemical changes occur as a consequence of cell density decline and altered matrix turnover (Galbusera et al., 2014). In the context of ECM composition, important age-

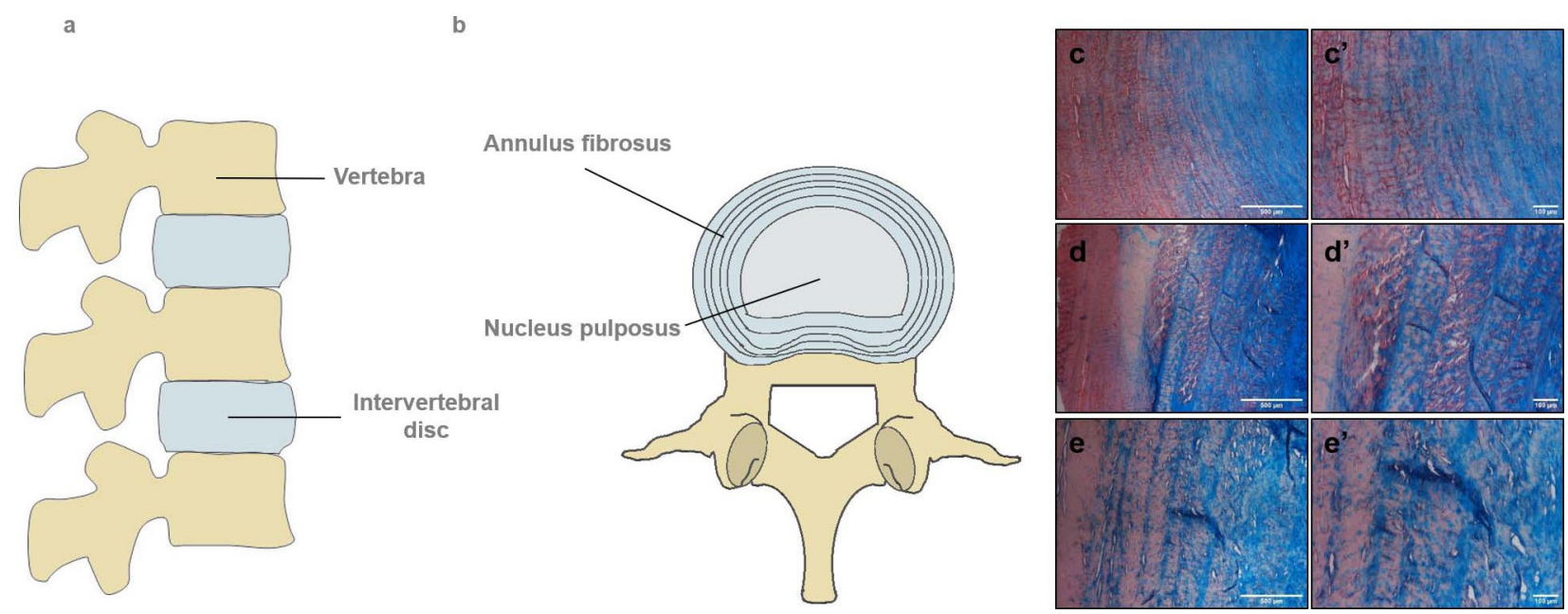

Fig. 1. Gross anatomy of the IVD and histological comparison of different-age bovine IVDs. (a) Lateral view of the spine illustrating the IVD laying between adjacent vertebrae. (b) Upper view with the different disc regions - the AF formed by concentric rings organised around the central NP. Picrosirius red, alcian blue and H\&E staining of $\left(\mathbf{c}, \mathbf{c}^{\prime}\right)$ foetus, $\left(\mathbf{d}, \mathbf{d}^{\prime}\right)$ young and $\left(\mathbf{e}, \mathbf{e}^{\prime}\right)$ old disc samples. GAGs are identified in blue, whereas collagens are coloured in red. For each image, the left region represents the outer AF and on the right is the NP. Note the smaller interlamellar space in foetal discs. In older IVDs, the layers present an irregular distribution with an increase in the interbundle spaces (optically empty spaces). Images were acquired at magnifications of $5 \times(\mathbf{c}, \mathbf{d}, \mathbf{e}$, scale bar $500 \mu \mathrm{m})$ and $10 \times\left(\mathbf{c}^{\prime}, \mathbf{d}^{\prime}, \mathbf{e}^{\prime}\right.$ scale bar $\left.100 \mu \mathrm{m}\right)$. 
associated alterations in the NP matrisome have been recently observed. The amount of fibronectin and prolargin increase with age, whereas collagen type XII and XIV are almost exclusively expressed in bovine foetal NPs (Caldeira et al., 2017). Others have also described a decrease in proteoglycan content, which results in water loss, increased expression of proteases as well as changes in collagen crosslinking and synthesis patterns (Adams and Roughley, 2006; Colombier et al., 2014; Cs-Szabo et al., 2002; Duance et al., 1998; Takaishi et al., 1997). As a result of such a homeostatic imbalance, the NP becomes much more fibrous and cartilaginous, affecting cell phenotype and ECM synthesis, in a degradative cascade that triggers LBP (Adams and Roughley, 2006).

Current therapies for LBP and IVD degeneration are mostly conservative, being addressed to control inflammation and relieve pain (Bydon et al., 2014). However, they do not eliminate the underlying pathology and, hence, cannot be considered longterm clinical solutions. Surgical treatment, namely discectomy, arthroplasty and lumbar fusion, is usually considered when the other options fail (Bydon et al., 2014). Nevertheless, these invasive treatments have limitations (Nasser et al., 2010; Onesti, 2004; Swann et al., 2016). Subsequent disc degeneration and recurrent herniation are major problems following surgery (Swartz and Trost, 2003). Spinal fusion, for instance, has been associated with long-term adverse consequences, such as dehydration, disc space narrowing, osteophyte formation and progressive degeneration of the adjacent segment (Schizas et al., 2010). Although PEEK cages have been introduced as an alternative to metallic implants (Novotna et al.,
2015), due to them presenting a more adequate load transfer and increased fusion success rate (Schimmel et al., 2016), their hydrophobic surface does not allow for protein absorption or cell adhesion, thus requiring further modifications to enhance cell attachment and biocompatibility (Novotna et al., 2015). IVD total replacement by a non-biological prosthesis represents an alternative but long-term results are limited due to prosthesis wear, often requiring revision surgery. With the lack of effective long-term solutions, there is an urgent need to develop novel therapeutic strategies that target IVD functional regeneration, improving LBP patients' lives.

IVD regeneration has been attempted using different strategies including protein injection (Masuda et al., 2006; Walsh et al., 2004), gene transfer (Leckie et al., 2012; Yue et al., 2016) and cell implantation (Okuma et al., 2000; Sakai et al., 2005). Still, only few treatment options have been effectively translated into the clinic (Veruva et al., 2014). Cellbased therapies, namely with MSCs, have been used in clinical trials, decreasing pain but without signs of tissue regeneration (Orozco et al., 2011). Obstacles remain to cell transplantation, including cell leakage, which potentially causes undesired extra-discal bone formation (Vadalà et al., 2012) and poor cell survival in the harsh IVD microenvironment (acidic $\mathrm{pH}$, low oxygen and limited access of nutrients). Several biomaterials have also been developed but much work is still needed to obtain clinically successful alternatives. Natural hydrogels (e.g. alginate, chitosan, agarose, collagen, chondroitin sulphate) are close to the NP matrix composition but do not meet its mechanical requirements (van Uden et al., 2017).

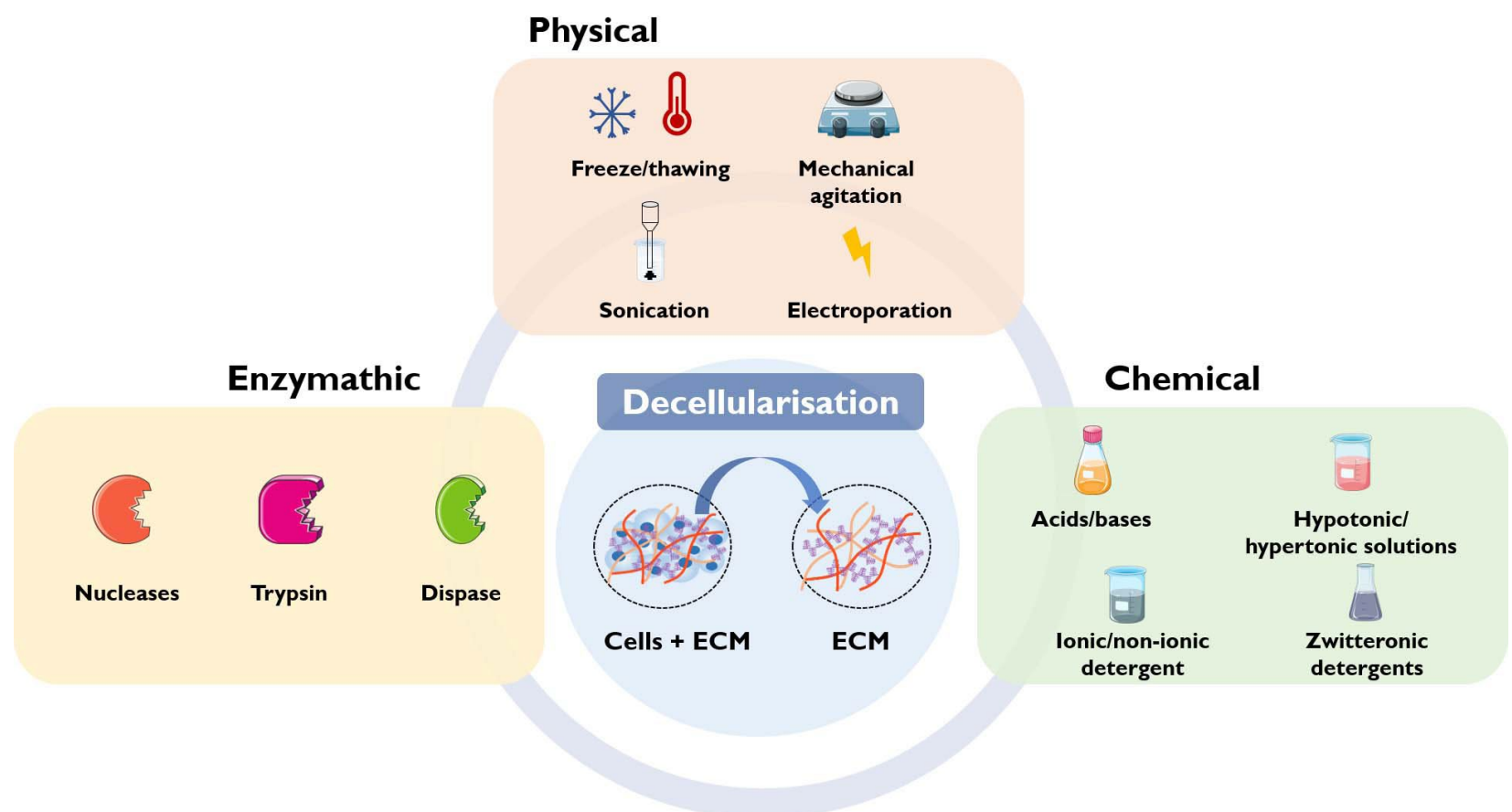

Fig. 2. Overview of decellularisation strategies. Tissue decellularisation can be performed by using physical (freeze-thawing, mechanical agitation, sonication, electroporation), chemical (acids or bases, hypotonic or hypertonic solutions, ionic or non-ionic detergents and zwitteronic detergents) and enzymatic (nuclease, trypsin, dispase) methods. For details, see Table 1. 
Table 1. Overview of agents and methods commonly used for decellularisation.

\begin{tabular}{|c|c|c|c|}
\hline Agent/methods & Mechanism of action & ECM effect & References \\
\hline \multicolumn{4}{|c|}{ Physical methods } \\
\hline Freeze-thawing & $\begin{array}{l}\text { Induces cell lysis by ice } \\
\text { crystal formation }\end{array}$ & $\begin{array}{l}\text { Preserves ECM proteins and } \\
\text { mechanical properties. ECM can be } \\
\text { disrupted with rapid freezing. }\end{array}$ & $\begin{array}{l}\text { Crapo et al. (2011) } \\
\text { Gilbert el al. (2006) } \\
\text { Gilpin and Yang (2017) }\end{array}$ \\
\hline Mechanical agitation & $\begin{array}{l}\text { Promotes diffusion of } \\
\text { solutions into the tissue and } \\
\text { removal of cellular debris }\end{array}$ & $\begin{array}{l}\text { ECM structure damage with } \\
\text { aggressive agitation or sonication }\end{array}$ & $\begin{array}{c}\text { Gilbert (2012) } \\
\text { Gilbert et al. (2006) }\end{array}$ \\
\hline Electroporation & $\begin{array}{l}\text { Disrupts cell membranes by } \\
\text { electrical pulse. }\end{array}$ & Disrupts ECM structure & Crapo et al. (2011) \\
\hline \multicolumn{4}{|c|}{ Chemical agents } \\
\hline Acids and bases & $\begin{array}{l}\text { Denature proteins, solubilise } \\
\text { cytoplasmatic elements and } \\
\text { disrupt nucleic acids }\end{array}$ & $\begin{array}{l}\text { Damage ECM components, } \\
\text { particularly collagen, GAGs and } \\
\text { growth factors }\end{array}$ & $\begin{array}{l}\text { Crapo et al. }(2011) \\
\text { Fu et al. }(2014)\end{array}$ \\
\hline $\begin{array}{l}\text { Hypotonic and } \\
\text { hypertonic solutions }\end{array}$ & $\begin{array}{c}\text { Provoke cell lysis by osmotic } \\
\text { shock and disruption of cell } \\
\text { membranes }\end{array}$ & $\begin{array}{l}\text { Enable cell debris washout from the } \\
\text { tissue }\end{array}$ & $\begin{array}{l}\text { Gilbert et al. (2006) } \\
\text { Zahmati et al. (2017) }\end{array}$ \\
\hline $\begin{array}{l}\text { Ionic detergents: } \\
\text { sodium dodecyl } \\
\text { sulphate }\end{array}$ & $\begin{array}{l}\text { Solubilises membrane } \\
\text { proteins }\end{array}$ & $\begin{array}{l}\text { Successfully removes cells from } \\
\text { dense tissues and organs } \\
\text { Perturbs tissue structure resulting in } \\
\text { loss of GAGs and collagen integrity }\end{array}$ & $\begin{array}{l}\text { Boccafoschi et al. (2017) } \\
\text { Crapo et al. (2011) } \\
\text { Fu et al. }(2014) \\
\text { Seddon et al. (2004) }\end{array}$ \\
\hline $\begin{array}{l}\text { Ionic detergents: } \\
\text { sodium deoxycholate }\end{array}$ & $\begin{array}{l}\text { Solubilises cells and nucleic } \\
\text { membranes }\end{array}$ & $\begin{array}{c}\text { Denatures ECM proteins, resulting in } \\
\text { GAGs and collagen loss }\end{array}$ & $\begin{array}{l}\text { Cheng et al. (2009) } \\
\text { Seddon et al. (2004) } \\
\text { White et al. (2017) }\end{array}$ \\
\hline $\begin{array}{l}\text { Non-ionic detergent: } \\
\text { Triton X-100 }\end{array}$ & $\begin{array}{l}\text { Disrupts lipid-lipid and } \\
\text { lipid-proteins interactions } \\
\text { and, to a lesser degree, } \\
\text { protein-protein interaction }\end{array}$ & $\begin{array}{c}\text { Less effective in DNA removal } \\
\text { Disrupts ECM structure with GAGs } \\
\text { loss. }\end{array}$ & $\begin{array}{l}\text { Boccafoschi et al. (2017) } \\
\text { Crapo et al. (2011) }\end{array}$ \\
\hline $\begin{array}{l}\text { Non-ionic detergent: } \\
\text { zwitterionic detergent }\end{array}$ & $\begin{array}{l}\text { Mixed properties of non- } \\
\text { ionic and ionic detergents }\end{array}$ & $\begin{array}{l}\text { Removes cells from tissue with } \\
\text { minimum disruption } \\
\text { More efficient in thin (e.g. lung) rather } \\
\text { than thick tissues }\end{array}$ & Crapo et al. (2011) \\
\hline \multicolumn{4}{|c|}{ Biological enzymes } \\
\hline Nucleases & $\begin{array}{l}\text { Hydrolyse ribonucleotide } \\
\text { and deoxyribonucleotide } \\
\text { chains }\end{array}$ & $\begin{array}{l}\text { Remove DNA from tissues } \\
\text { Enzyme residuals can provoke an } \\
\text { immune response }\end{array}$ & $\begin{array}{l}\text { Crapo et al. }(2011) \\
\text { Keane et al. }(2015) \\
\text { Vernengo et al. }(2020)\end{array}$ \\
\hline Trypsin & $\begin{array}{l}\text { Cleaves peptide bonds on } \\
\text { the carboxyl side of arginine } \\
\text { or lysine }\end{array}$ & $\begin{array}{l}\text { Effective as a decellularisation } \\
\text { adjuvant; however, long exposure can } \\
\text { disrupt tissue structure and remove } \\
\text { ECM proteins }\end{array}$ & $\begin{array}{l}\text { Crapo et al. (2011) } \\
\text { Keane et al. (2015) }\end{array}$ \\
\hline Dispase & $\begin{array}{l}\text { Cleaves fibronectin and } \\
\text { collagen IV }\end{array}$ & $\begin{array}{l}\text { Used for several tissues (e.g. porcine } \\
\text { skin and corneas), however needs to } \\
\text { be combined with additional agents } \\
\text { to perform efficient decellularisation } \\
\\
\text { It can damage ECM structure and } \\
\text { remove fibronectin and collagen IV } \\
\text { with long exposure }\end{array}$ & $\begin{array}{l}\text { Crapo et al. (2011) } \\
\text { Keane et al. (2015) }\end{array}$ \\
\hline
\end{tabular}


In turn, synthetic materials (e.g. polyethylene glycol and polyvinyl alcohol) provide better biomechanical properties but have poor biocompatibility.

Decellularised ECM-based scaffolds, have received significant attention and started to be widely used in different tissues (cardiac valves, vascular grafts, cornea, etc.) (Mercuri et al., 2011). Given their pro-regenerative potential, they are currently being commercialised for many different therapeutic applications and could be a promising alternative for IVD regeneration (Gilbert et al., 2006). Recently, the combination of decellularised ECM and bioprinting has started to be explored for IVD and cartilage. Although this strategy is still at an early stage, the use of this novel technique may improve the design of IVD-based scaffolds (Vernengo et al., 2020). The present review summarises recent advances in IVD decellularisation and discusses the need for novel therapeutic solutions for disc regeneration.

\section{IVD decellularisation methods}

Decellularisation is the technique used to remove host cells from tissues or organs (Londono and Badylak, 2015). Decellularised scaffolds should provide the same or similar microenvironment for seeded cells as native ECM (Xu et al., 2014). However, most decellularisation methods affect ECM properties at least to some extent. Several decellularisation procedures and agents have been investigated to overcome matrix disruption and preserve its composition. Optimal decellularisation methods vary from different tissues or organs, depending on specific features: tissue size, thickness, shape, cell and matrix density (Vernengo et al., 2020; White et al., 2017). Following decellularisation, the efficiency of the process can be evaluated considering several aspects, including the presence of DNA and cell removal. As such, acellular scaffolds should have less than $50 \mathrm{ng}$ dsDNA/mg ECM dry weight, less than $200 \mathrm{bp}$ DNA fragment and no visible cell nuclei (Gilpin and Yang, 2017). Also, matrix proteins content (collagen, laminin, fibronectin, GAGs, growth factors) as well as mechanical properties should be analysed and maintained as close to native tissue as possible (Gilpin and Yang, 2017). In the end, even if cell residues such as DNA, RNA, cell membrane and debris remain, the decellularised scaffold needs to be biocompatible to avoid immune or inflammatory reactions (Crapo et al., 2011). Cell removal should be maximised while minimising adverse effects on ECM composition, biological activity, integrity and biomechanical properties (Hoshiba et al., 2010). An overview of the most commonly used decellularisation methods (physical, chemical and enzymatic) is shown in Fig. 2 (for further details see supplementary Table 1).

In recent years, decellularisation is being widely investigated as a novel strategy to develop functional substitutes for allogenic transplantation and resolve the major problems encountered in the clinic, such as donor shortage and immunosuppression (Tapias and $\mathrm{Ott}, 2014)$. Although several decellularised ECM scaffolds have already been approved by the FDA and are being commercialised for clinical applications (Alloderm $^{\circledR}$, SurgiSIS $^{\circledR}$, Restore ${ }^{\circledR}$, ACell, Synergraft $^{\circledR}$ ) (Gilbert et al., 2006), many challenges remain. Several attempts have been made to develop an ideal IVD decellularisation protocol through the combination of numerous enzymatic, physical and chemical methods (Table 2) but a satisfactory method is still to be defined. GAGs loss after decellularisation is one of the major issues to be solved. Large amounts of GAGs could improve IVD biomechanical properties after decellularisation, namely by increasing ECM compressive properties. Recent research is focusing on the development of more efficient and milder protocols that could preserve GAGs in IVD-based scaffolds (Vernengo et al., 2020).

\section{NP tissue decellularisation}

Simionescu's group was the first to establish a decellularisation protocol for the IVD (Mercuri et al., 2011). They were able to create a porcine decellularised NP-based scaffold by using a combination of Triton X-100 and deoxycholic acid detergents, ultrasonication and nucleases (DNAse and RNAse). Although the protocol was efficient in removing cells from the NP, it also affected tissue ultrastructure as well as ECM composition, leading to a $49 \%$ GAGs loss. Decellularised scaffolds contained nearly twice as much collagen as fresh tissues (decellularised NPs: $75.24 \mu \mathrm{g} / \mathrm{mg}$; fresh NPs: $36.20 \mu \mathrm{g} / \mathrm{mg}$ ). This apparent increase corresponds to a decrease in other tissue components (Mercuri et al., 2011). After optimising decellularisation conditions, they showed higher Col2 expression in porcine explants seeded with human ADSCs, when cultured in a differentiation medium as compared to normal DMEM at days 7 and 14 (9-fold vs. 2-fold increase, respectively). Expression of PAX-1, SOX9, COL3 and TIMP-1 was also upregulated. Additionally, GAG content of seeded scaffolds cultured in differentiation medium was significantly higher than for non-seeded ones, after $7 \mathrm{~d}$ (non-seeded NPs: $18.3 \mu \mathrm{g} / \mathrm{mg}$; repopulated NPs: $34.74 \mu \mathrm{g} / \mathrm{mg}$ ) and $14 \mathrm{~d}$ (non-seeded NPs: $20.6 \mu \mathrm{g} / \mathrm{mg}$; repopulated NPs: $46.28 \mu \mathrm{g} / \mathrm{mg}$ ) (Mercuri et al., 2013). Recently, the same group performed a screening of different conditions to decellularise bovine NPs. The authors increased treatment time as well as amount of detergents and concentration of DNAse used. They found that $1.2 \%$ of Triton X-100 treatment for $72 \mathrm{~h}$ combined with ultrasonication was the optimal procedure for bovine samples. An ethanol wash prior to decellularisation was used to guarantee total detergent absorption. This protocol removed $93 \%$ of DNA, while retaining around $30 \%$ of GAGs and high collagen levels (decellularised NP: 13.87 HYP/ mg sample dry weight; native NPs: $8.63 \mu \mathrm{g} \mathrm{HYP} / \mathrm{mg}$ 


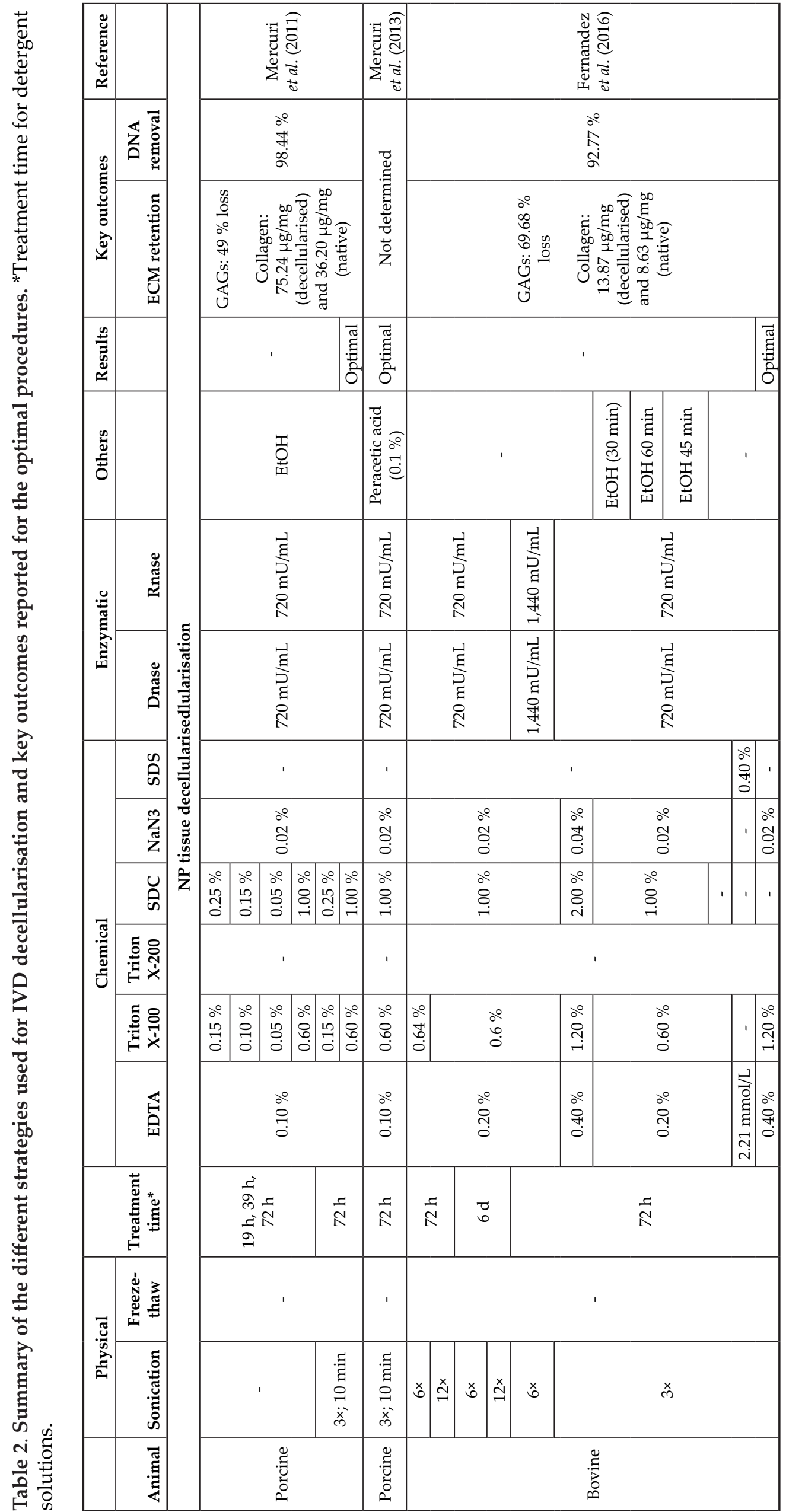




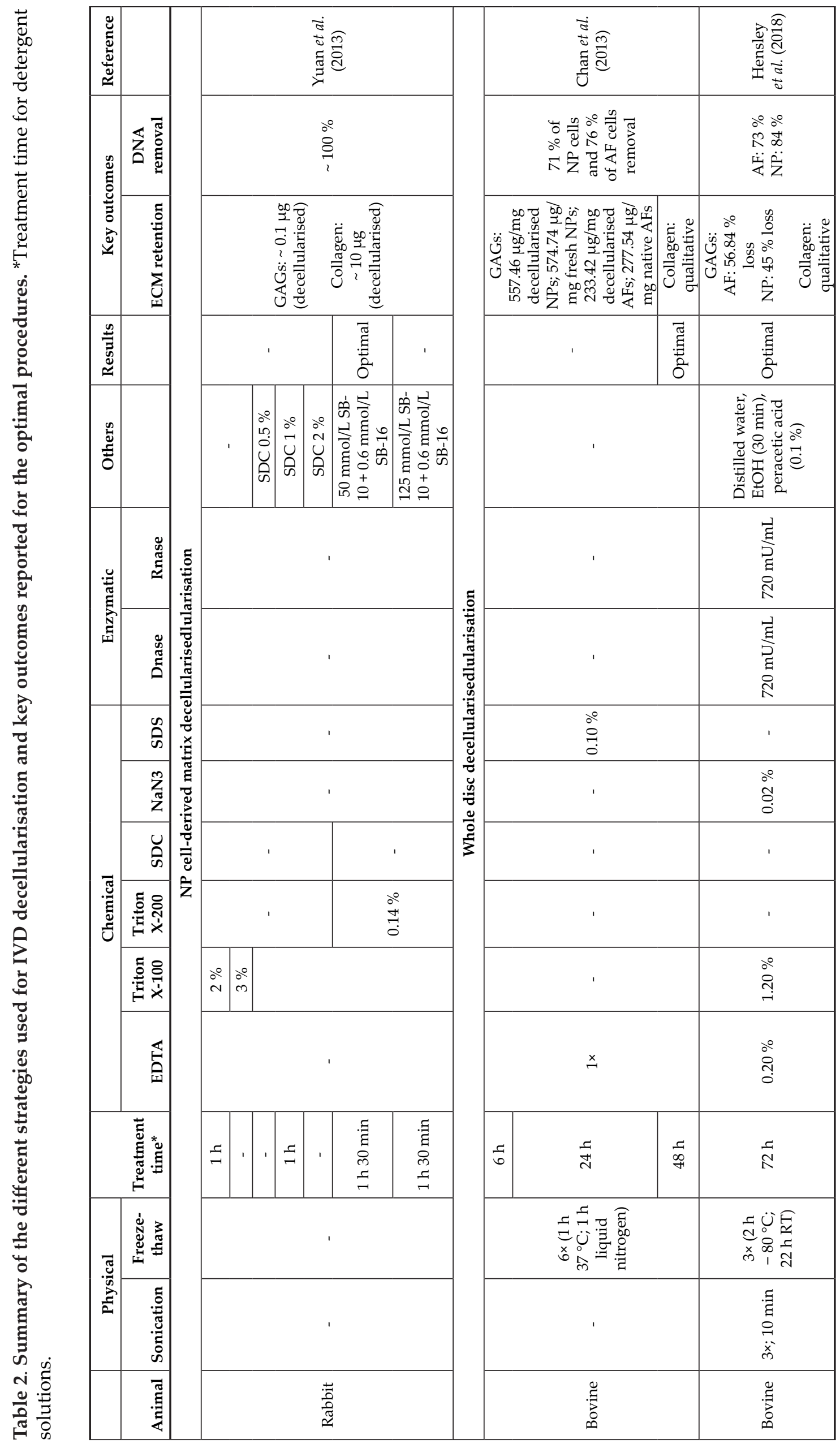




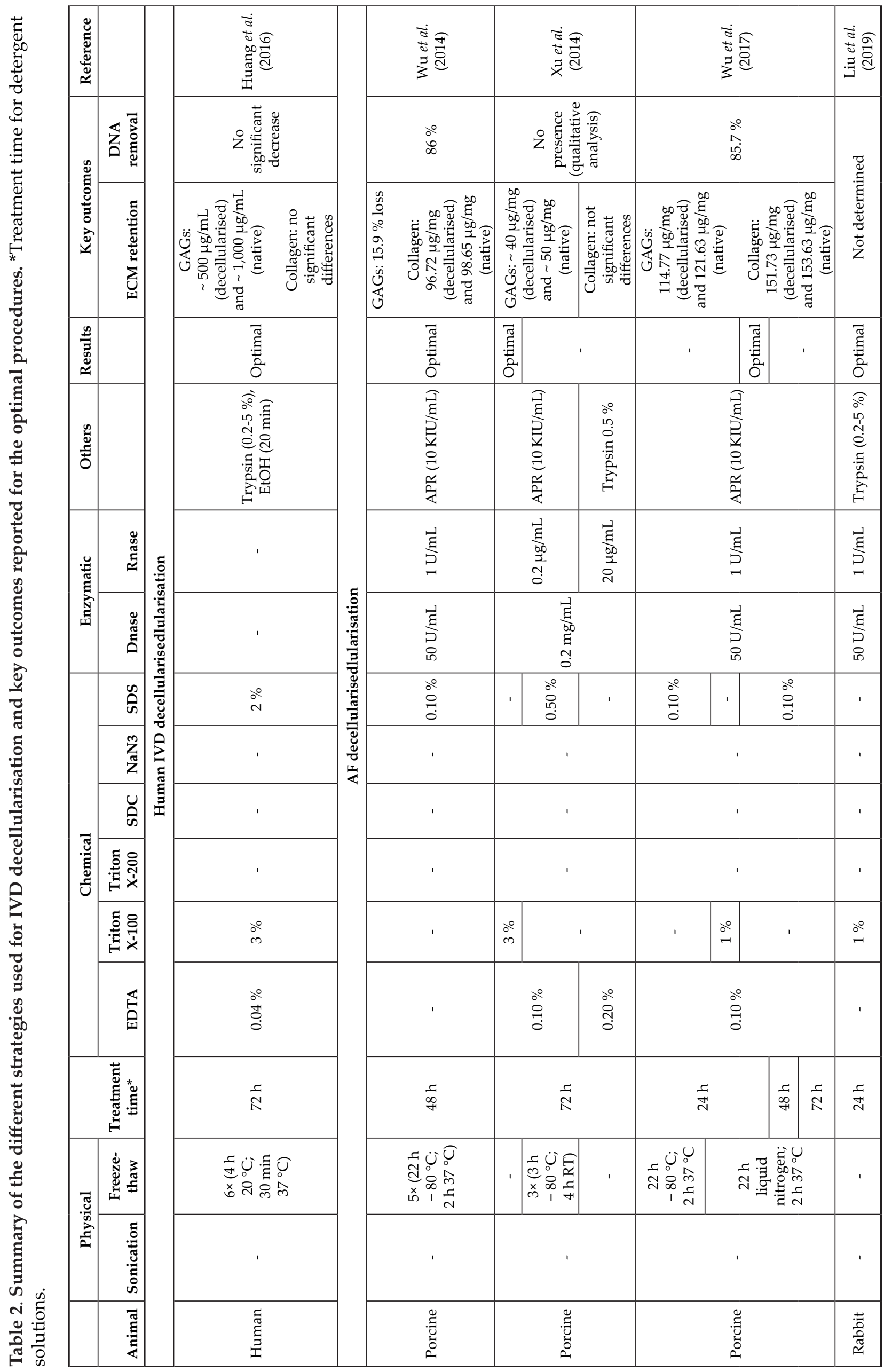


sample dry weight). Mechanical features resembled those of native NPs. It is still necessary to discover whether a similar protocol without sonication would be less disruptive to the ECM structure (Fernandez et al., 2016). Indeed, ECM architecture of bovine NP was disrupted following decellularisation, when ultrasonication was applied (unpublished data).

\section{NP-cell-derived matrix decellularisation}

Yuan et al. (2013) focused on the decellularisation of in-vitro-derived rabbit NP matrices (deposited onto collagen microsphere templates), which were used to instruct human MSC differentiation towards NP-like lineages. A combinatorial protocol of Triton X-200 with SB-10 and SB-16 avoided fast transitions of detergents to water, causing less structural damage than using them separately. Zwitterionic and anionic detergents removed most cell components while retaining around $0.1 \mu \mathrm{g} / 100 \mu \mathrm{L}$ of solubilised GAGs from 30 microspheres and $10 \mu \mathrm{g}$ of collagen per $100 \mu \mathrm{L}$ of sample digest, by generating smaller surfactant micelles that were able to easily penetrate into the tissue. Higher detergent concentrations might have had reduced decellularisation effectiveness since emulsifying micelles were too large to penetrate into the collagen microspheres (Yuan et al., 2013). The obtained scaffolds were further characterised by proteomics, demonstrating partial preservation of the ECM microenvironment (Yuan et al., 2018).

\section{AF decellularisation}

Concerning the development of acellular AFs, Huang's lab used a combination of repeated freeze-thawing followed by incubation in $0.1 \%$ SDS for $48 \mathrm{~h}$ to decellularise porcine tissue ( $\mathrm{Wu}$ et al., 2014). A reduction of $86 \%$ in DNA content and $16 \%$ in GAGs was achieved in decellularised AF-based scaffolds when compared to fresh ones. No significant differences were seen in collagen content (fresh AF: $98.65 \mu \mathrm{g} / \mathrm{mg}$; decellularised AF: $96.72 \mu \mathrm{g} / \mathrm{mg})$. Although stiffness and Young's modulus have exhibited a tendency to decrease after decellularisation, these differences were not statistically significant (Wu et al., 2014). In contrast, Xu et al. (2014) compared different AF decellularisation protocols and demonstrated that $3 \%$ Triton X-100 treatment for $72 \mathrm{~h}$ was better than a freeze-thawing combination with a $0.5 \%$ SDS treatment or even a trypsin-based enzymatic method. In this study, the Triton X-100-based protocol enabled the maintenance of biomechanical properties without affecting tissue structure and, also, retained the highest GAG content ( $\sim 40 \mathrm{~g}$ GAG/mg dry weight) (Xu et al., 2014). 3 years later, Huang's group validated the previous results but reducing the treatment time to $24 \mathrm{~h}$, given that extension of the decellularisation time had a greater effect on collagen (fresh AF: $120.94 \mu \mathrm{g} / \mathrm{mg}$; decellularised AF for $24 \mathrm{~h}$ : $109.72 \mu \mathrm{g} / \mathrm{mg}$; decellularised AF for $48 \mathrm{~h}$ : $94.18 \mu \mathrm{g} / \mathrm{mg}$; decellularised AF for $72 \mathrm{~h}: 89.80 \mu \mathrm{g} /$ mg) and GAGs (fresh AF: $96.09 \mu \mathrm{g} / \mathrm{mg}$; decellularised AF for $24 \mathrm{~h}: 82.77 \mu \mathrm{g} / \mathrm{mg}$; decellularised AF for $48 \mathrm{~h}$ : $47.49 \mu \mathrm{g} / \mathrm{mg}$; decellularised AF for $72 \mathrm{~h}: 14.44 \mu \mathrm{g} /$ mg) content (Wu et al., 2017). Finally, Liu et al. (2019) created a hydrogel by combining rabbit decellularised $\mathrm{AF}$, chitosan and genipin as crosslinker. The tissue was decellularised using a similar protocol to that of Huang's group after tissue digestion with trypsin. bFGF incorporation promoted expression of ECM genes and corresponding proteins in the supernatants of seeded rabbit AF stem cells (Liu et al., 2019).

\section{Whole disc decellularisation}

Chan et al. (2013) reported, for the first time, decellularisation of an entire bovine IVD (including the endplates). They tried different SDS washing temperatures and freeze-thawing cycles to preserve GAG and collagen content. With 6 freeze-thaw cycles followed by $48 \mathrm{~h}$ washing with SDS $0.1 \%$ at $4{ }^{\circ} \mathrm{C}$, the authors succeeded in removing over $70 \%$ of the cells in both the AF and NP. The protocol was improved by increasing the number of freeze-thaw cycles, which completely abolished metabolic activity of the remaining cells. After decellularisation, both NP and AF maintained a GAG content similar to native tissue (fresh NP: $574.74 \mu \mathrm{g} / \mathrm{mg}$; decellularised NP: $557.46 \mu \mathrm{g} / \mathrm{mg}$; fresh AF: $277.54 \mu \mathrm{g} / \mathrm{mg}$; decellularised AF: $233.42 \mu \mathrm{g} / \mathrm{mg}$ ). Mechanical properties were also preserved. This enabled NP cell penetration after $7 \mathrm{~d}$ in culture (Chan et al., 2013).

5 years later, Mercuri's group also tried to decellularise a complete disc xenograft. To obtain large (C1-C4) acellular bovine scaffolds, they used a longer Triton-based protocol [adapted from the one for NP (Fernandez et al., 2016)]. However, unlike Chan et al. (2013), they did not include the cartilaginous endplates. No significant differences were observed in swelling pressure or in toe-region modulus between decellularised and native tissues. However, decellularised IVDs showed a decrease of linear-region moduli, peak stress and equilibrium moduli (Hensley et al., 2018).

\section{Human IVD decellularisation}

In 2016, Schulze-Tanzil's lab was able to decellularise human IVDs from elder individuals undergoing spinal fusion or disc replacement. They adopted a protocol based on the combination of freeze-thawing, trypsin digestion and chemical detergents (2\% SDS and $3 \%$ Triton X-100). Although decellularised IVDs contained almost half the GAGs content, as compared to native tissues, matrix architecture was maintained within the decellularised IVD cylindrical punches. Although cell removal was gauged by lack of nuclear and H\&E staining, no significant differences were observed in total DNA content by the CyQuant Assay. In addition, despite the larger numbers of human IVD cells found in repopulated scaffolds, only differentiated MSCs were capable of increasing collagen and GAG content (Huang et al., 2016). 


\section{Injectable strategies for decellularised matrix administration}

In recent years, the use of ECM-based scaffolds has advanced with the development of injectable and biocompatible hydrogels (Hussey et al., 2018).

Hydrogels are defined as highly hydrated polymer materials that are able to preserve their structural integrity by physical and chemical crosslinks between chains (Saldin et al., 2017). The development of hydrogels from decellularised tissue is guided by the presence of biochemical factors and proteins of decellularised tissue through a collagen-based self-assembly process (Saldin et al., 2017). Injectable ECM-based hydrogels can be formed mainly using two different methods. The first approach consists of grinding or milling the ECM into a fine powder, followed by resuspension in a solvent prior to injection. The second method consist of digesting enzymatically the ECM in an acidic solution and subsequently neutralising the $\mathrm{pH}$ and salt concentration to mimic in vivo physiological conditions. After digestion, the ECM can form a hydrogel by thermal crosslinking (Spang and Christman, 2018). Pepsin is the most used enzyme for tissue solubilisation, since it digests most protein structures (Hulmes, 2008) and hydrolyses collagen (León-López et al., 2019). However, dispase can be an alternative for soft tissues (Saldin et al., 2017).

In the disc field, hydrogels provide biochemical and biological signals to drive NP repair and regeneration and constitute a promising cell delivery system for minimally invasive strategies to treat IVD degeneration.

Illien-Junger et al. (2016) were able to develop decellularised injectable bovine NP fragments by using a protocol based on SDC. Prior to treatment, all samples went through a process of freeze-thawing, lyophilisation and grinding to increase surface area, facilitating fragment suspension. To test its injectability, the hydrated ECM suspension was transferred into a dual-barrel syringe and injected through a 25-G needle into an injured IVD. Apart from the optimal protocol using $2 \%$ deoxycholate and DNAse, other treatments tested included additional decellularisation steps with $2 \%$ SDS and $0.1 \%$ Triton X-100. These alternatives produced looser scaffolds with thicker fibres and resulted in increased DNA levels with minimal GAG and collagen content. Interestingly, several cell-seeded constructs were immersed in low-melting-point agarose to create a protective shell that avoided swelling and dissociation. No cytotoxicity was observed, neither with human NP cells nor MSCs, after $21 \mathrm{~d}$ in culture (Illien-Junger et al., 2016).

Lin et al. (2016) were also able to develop ECM microparticles from decellularised rabbit IVD by grinding the tissues. Following homogenisation, the obtained microparticles were passed through a sieve and their size was confined to smaller than $200 \mu \mathrm{m}$. Acellular IVD derived-microparticles injected using a 27-G needle prevented disc degeneration in a rabbit model, by increasing water level and disc height as well as ECM integrity and content (Lin et al., 2016).

Lin and co-workers optimised porcine NP decellularisation using an SDS-based method that could remove up to $95.1 \%$ of DNA and still maintain tissue microstructure and ECM components, particularly collagen (decellularised NP: $174.8 \mu \mathrm{g} / \mathrm{g}$; native NP: $90.3 \mu \mathrm{g} / \mathrm{g}$ ). However, GAGs decreased after decellularisation (decellularised NP: $19.33 \mu \mathrm{g} / \mathrm{mg}$; native NP: $22.84 \mu \mathrm{g} / \mathrm{mg}$ ). Moreover, mass spectrometry revealed the presence of important signalling molecules (e.g. lactadherin, metallopeptidase inhibitor 1 and alpha-1-antitrypsin) in NP-ECM scaffolds, which are involved in several cell activities. Particularly, TGF- $\beta 1$, a protein associated with NP cells differentiation, was also detected. After repopulation with MSCs, NP-related genes (COL2A1, ACAN and SOX9) were upregulated in the NP-ECM scaffolds when compared to the controls as well as TGF- $\beta R 2$ at an early culture stage ( $3 \mathrm{~d})$. Finally, IF showed higher synthesis of NP-cell-related proteins (ACAN and SOX9) in the repopulated scaffolds. These results suggested that NP-ECM scaffolds were able to induce MSC differentiation towards NP-like cells through the activation of TFG- $\beta 1$ signalling pathway ( $\mathrm{Xu}$ et al., 2019). After reseeding, decellularised NPs were cut into small pieces to allow the passage through a 25-G needle. Following resuspension, ECM fragments were injected into a rabbit model of disc degeneration. Following 4 and 8 weeks of injection, NP structure and IVD disc height were preserved, when compared to a degenerated IVD group. Although proteoglycans were partially lost, as shown by a reduction of safranin $\mathrm{O}$ staining, the typical ECM network structure was still maintained at 8 weeks upon injection. Overall, reseeded scaffolds were able to delay disc degeneration in vivo (Xu et al., 2019).

Wachs et al. (2017) developed, for the first time, a NP-based hydrogel from porcine tissue. The protocol was based on the combination of SB-10, Triton X-200 and SB-16 detergents and similar to that used by Yuan et al. (2013) for in-vitro-derived matrices. Instead of injecting a resuspension of lyophilised particles as in Illien-Junger et al. (2016), dried scaffolds were digested in an acidic solution and then neutralised with sodium hydroxide. The newly formed hydrogel retained native tissue architecture and was used to culture human NP cells that were able to acquire an elongated morphology and increased their GAG content over time, specifically from around $100 \mathrm{ng} /$ $\mathrm{mg}$ on day 7 to $250 \mathrm{ng} / \mathrm{mg}$ on day 21 (Wachs et al., 2017).

$\mathrm{Yu}$ and colleagues created an injectable and thermosensitive decellularised NP-based hydrogel from bovine tissue, suitable for minimally invasive applications. Following decellularisation with a combination of freeze-drying and SDS $1 \%$ treatments, tissues were lyophilised, ground to a powder and digested in an acidic solution, using 
a similar method to that of Wachs et al. (2017). Afterwards, digested NPs were turned into hydrogels at $37^{\circ} \mathrm{C}$. The hydrogels were not cytotoxic and were well tolerated (Yu et al., 2020).

Zhou et al. (2018) decellularised porcine NPs using Wachs' protocol (Wachs et al., 2017). As IllienJunger et al. (2016) and Lin et al. (2016) had done earlier, they fragmented the decellularised samples. Since decellularisation treatments can affect ECM ultrastructure, with a decrease in protein content, particularly GAGs, Zhou and colleagues decided to supplement the acellular scaffold with chondroitin sulphate $(20 \mathrm{mg} / \mathrm{mL})$ to obtain a GAG/HYP ratio similar to that of the native tissue. Human or rabbit ADSCs were encapsulated and this gel crosslinked using $0.02 \%$ genipin (higher genipin concentrations were cytotoxic). The hydrogel was able to induce NPlike differentiation in vitro and partially recover the degenerated NP in vivo, in a rabbit IVD degeneration model (Zhou et al., 2018). Finally, Peng and colleagues developed an injectable genipin-crosslinked decellularised AF hydrogel (g-DAF-G) from bovine tissue that was able to direct human BM-MSCs differentiation towards an AF-cell-like phenotype in vitro. AF decellularisation was achieved by using a combination of freeze-drying cycles, Triton X-100 (2\%) and SDS (1\%) detergents and sterile water. After lyophilisation, decellularised AF samples were digested in $0.01 \mathrm{~mol} / \mathrm{L} \mathrm{HCl}$ containing $1.5 \mathrm{mg} / \mathrm{mL}$ pepsin under moderate agitation for $48 \mathrm{~h}$ to create a decellularised AF-based hydrogel (DAF-Gs). Finally, hydrogels were crosslinked using genipin, forming g-DAF-G. The storage modulus ( $\left.G^{\prime}\right)$ of g-DAF-G was superior to that of DAF-G and increased with higher concentration of genipin (DAF-G: $465.51 \mathrm{~Pa}$; $0.01 \%$ genipin: $2.57 \mathrm{MPa}$; $0.02 \%$ genipin: $3.29 \mathrm{MP}$; 0.04 \%genipin: $4.34 \mathrm{MPa}$ ). Therefore, g-DAF-G showed improved biomechanical properties when compared to DAF-G (Peng et al., 2020).

Apart from being used for hydrogel formation, solubilised decellularised matrices can also be used as coating of 2D substrates by adsorbing ECM proteins onto a tissue culture surface, as has been performed for other tissues (Agmon and Christman, 2016; DeQuach et al., 2010; Lee et al., 2014). Despite that they no longer retain native tissue architecture, coated plates will provide biochemical signals that can be sensed by the seeded cells, which will change their behaviour accordingly.

\section{Sterilisation of decellularised IVD matrices}

Considering that implant-associated infections are one of the major issues halting the widespread use of biomaterials in the clinics (Campoccia et al., 2006; Li and Webster, 2018), the optimisation of the sterilisation methods for ECM-based scaffolds is crucial before their clinical application.
Acidic solutions or solvents, heat treatment, ethylene oxide exposure, iodine and irradiation (gamma or electron beam), represent some of the methods available for scaffold sterilisation. Freeze-drying and supercritical carbon dioxide are also currently being tested (Dai et al., 2016). A combination of different techniques can be required to achieve complete removal of viral or bacterial contaminants from biomaterials. Sterilisation conditions should be tightly controlled and poststerilisation effects evaluated individually. Problems that might arise from matrices' sterilisation include insufficient cell penetration upon repopulation, incomplete microorganism inactivation, cell toxicity and loss of integrity (Crapo et al., 2011; Dai et al., 2016). Therefore, sterilisation can compromise efficiency of biomaterials. Several approved and standardised methods of sterilisation (e.g. heat, pressure, irradiation, chemical agents, supercritical carbon dioxide and ionised gas plasma) can induce degradation of ECM components, thus modifying its physiological and biomechanical properties (Fidalgo et al., 2018).

One option that has been used for IVD scaffold culture in sterile conditions is the addition of antibiotics or antifungal solutions such as sodium azide or a combination of penicillin and streptomycin (Lin et al., 2016; Mercuri et al., 2013; Yuan et al., 2013). Peracetic acid $(0.1 \%$ or $0.01 \%)$ might also be used in combination with an antibiotic infusion (Mercuri et al., 2013; Zhou et al., 2018). $70 \%$ ethanol is another alternative (Huang et al., 2016; McGuire et al., 2017; Mercuri et al., 2011) although the final objective of at least some of the authors does not seem to be sterilisation but only tissue dehydration (Fernandez et al., 2016; Huang et al., 2016). In addition, it can denature proteins, dehydrate ECM and affect cellECM interactions (Poornejad et al., 2015).

Xu et al. (2019) used gamma irradiation to sterilise porcine NP scaffolds. Nevertheless, at least for porcine renal decellularised matrices, Poornejad et al. (2015) showed that $0.2 \%$ peracetic acid in $1 \mathrm{~mol} / \mathrm{L}$ $\mathrm{NaCl}$ solution presented the best results in terms of GAG content and ECM structure preservation, rather than gamma-irradiation, ethanol alone or even peracetic acid in $4 \%$ of alcohol. In this study, gamma-irradiation was the most damaging sterilisation method since it caused modification of tissue microstructure and considerable reduction of ECM components (collagen and GAGs) as well as increased tissue porosity and altered mechanical properties. Significant decrease of cell adhesion and proliferation after scaffold repopulation were also observed (Poornejad et al., 2015). Badylak's group demonstrated that a high dose of gamma-irradiation (30 kGy) prevented hydrogel formation from ECM of several tissues (porcine intestinal submucosa, liver and urinary bladder, bovine bone), when compared to the supercritical $\mathrm{CO}_{2}$ method (White et al., 2018). Finally, Peng et al. (2020) adopted a combination of 


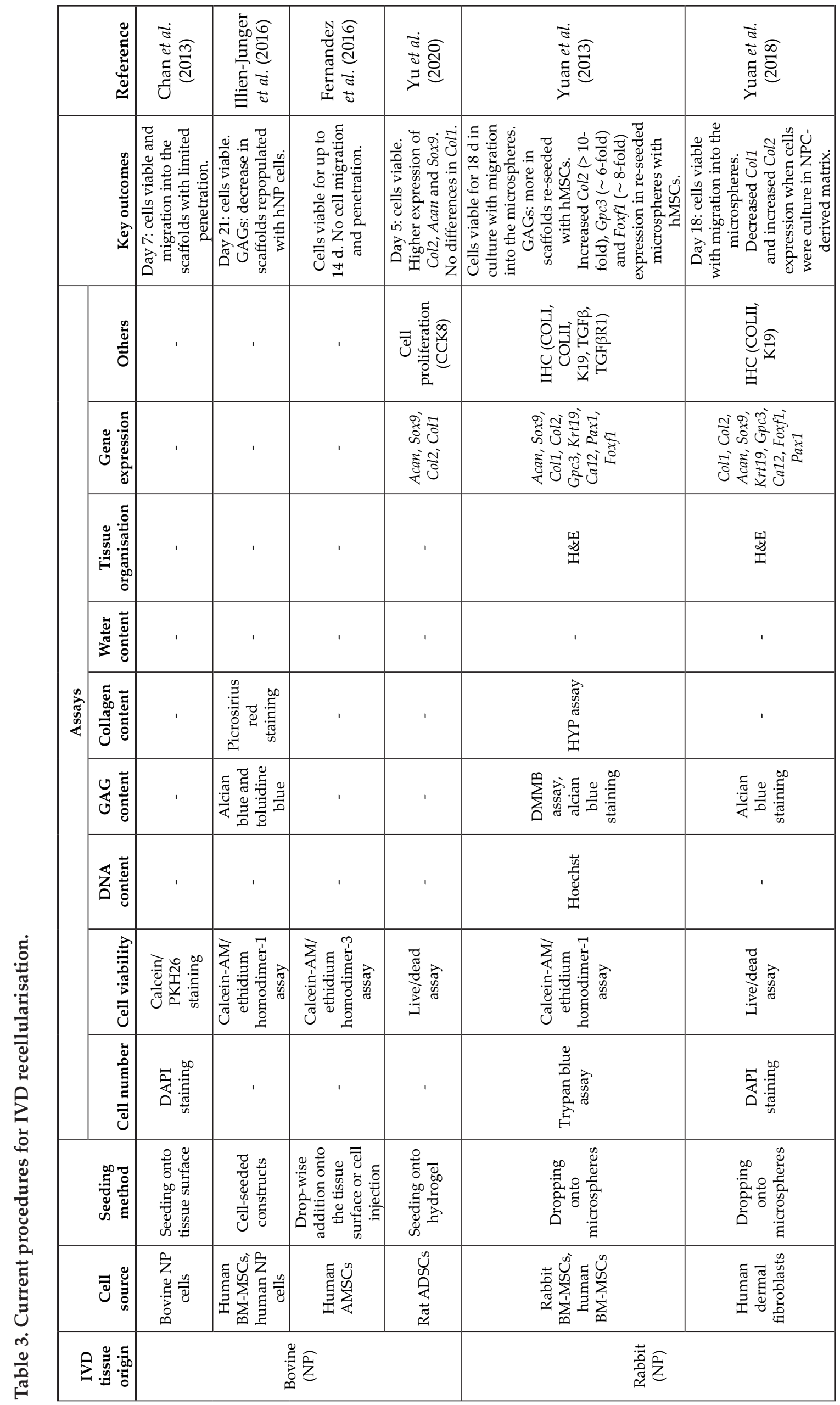




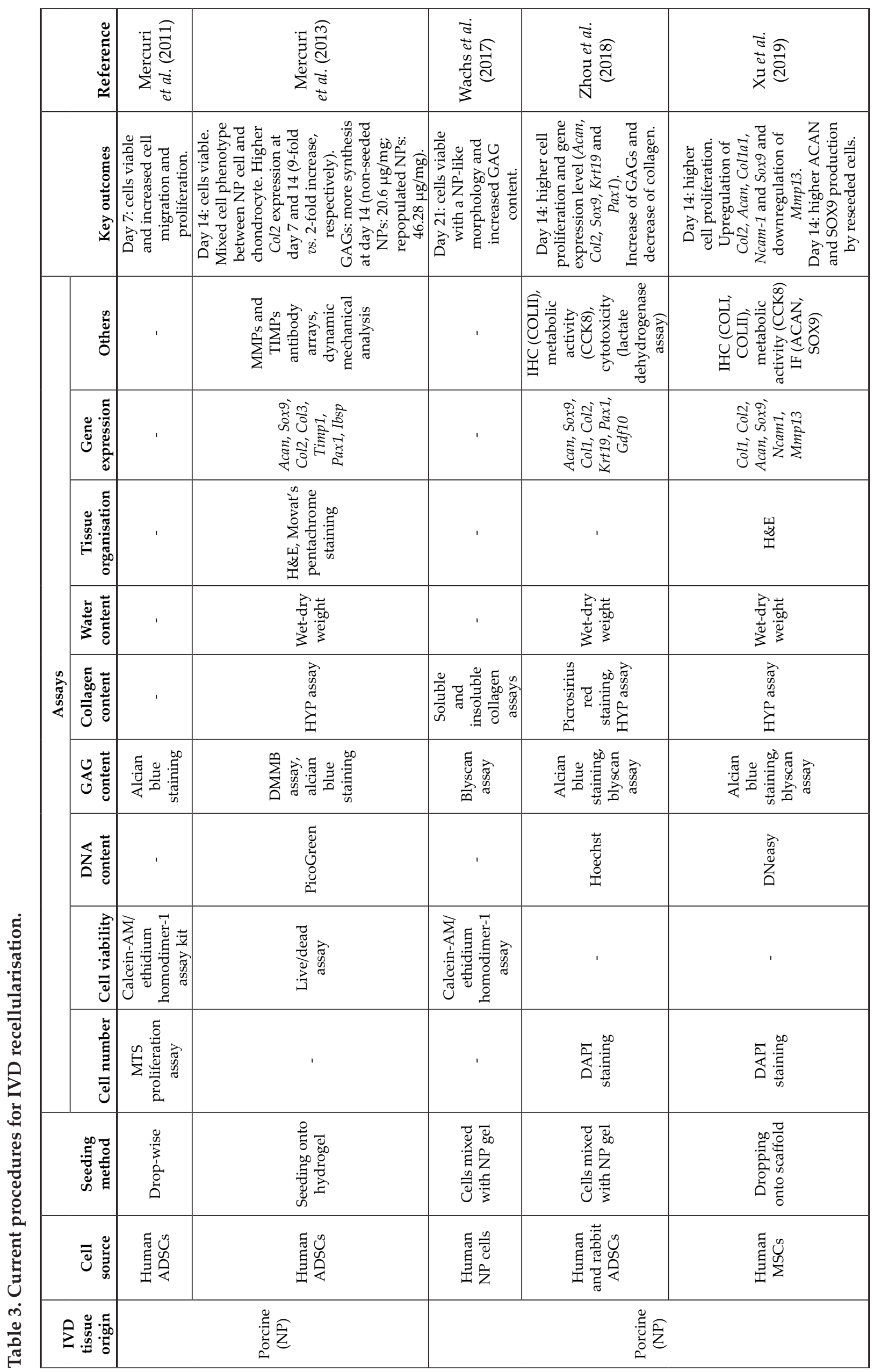




\begin{tabular}{|c|c|c|c|c|c|}
\hline 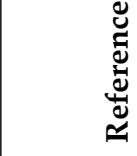 & 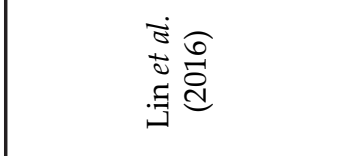 & 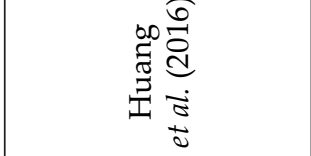 & 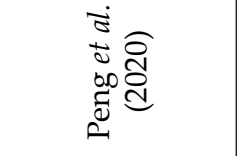 & 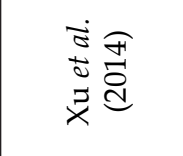 & $\begin{array}{l}\dot{\vec{s}} \widehat{\sigma} \\
\stackrel{\Xi}{\vec{S}}\end{array}$ \\
\hline 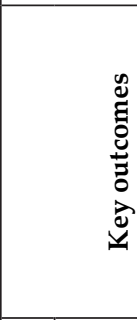 & 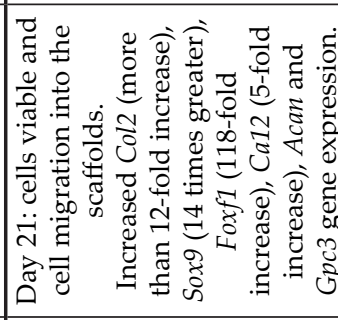 & 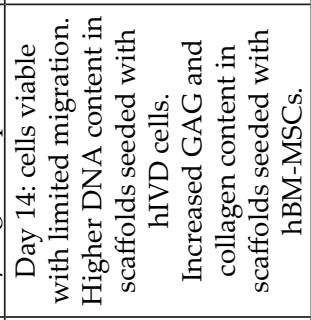 & 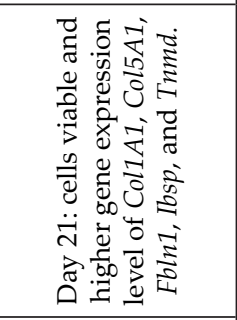 & 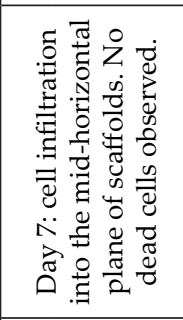 & 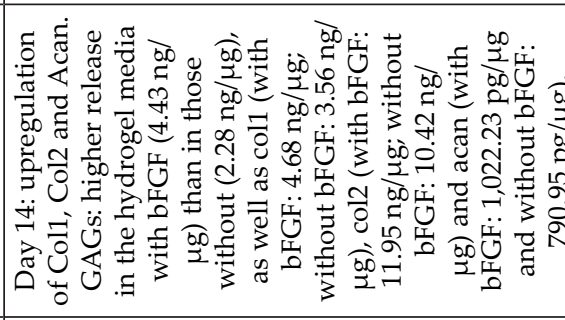 \\
\hline 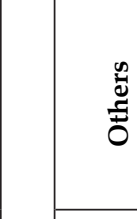 & 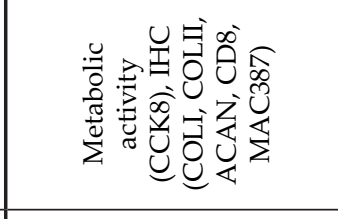 & & 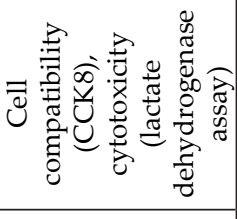 & , & 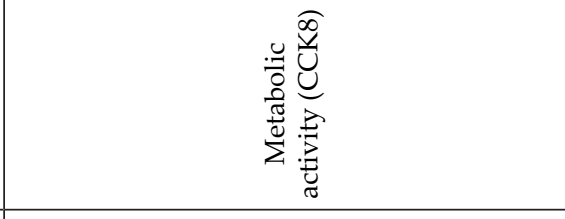 \\
\hline 总高 & 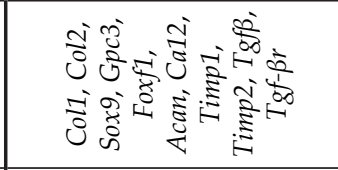 & 1 & 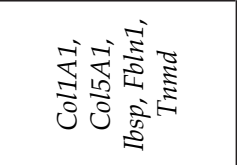 & ' & 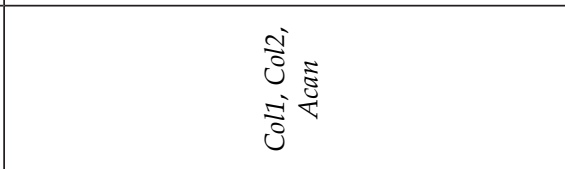 \\
\hline 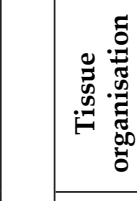 & 罯 & ' & & $\begin{array}{l}\text { 罡 } \\
\end{array}$ & ' \\
\hline 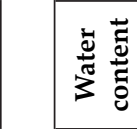 & 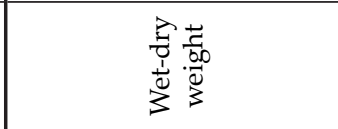 & & & ' & \\
\hline 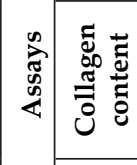 & 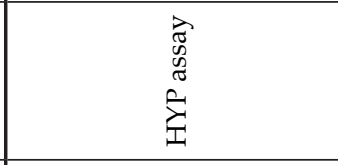 & 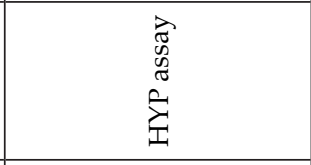 & & ' & 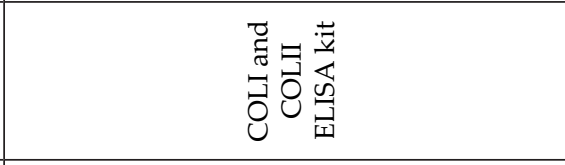 \\
\hline 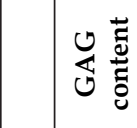 & 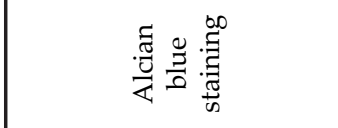 & 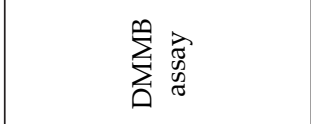 & & . & 密咢 \\
\hline 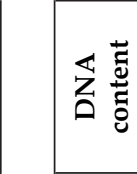 & $\begin{array}{l}\text { 密 } \\
\text { पू }\end{array}$ & 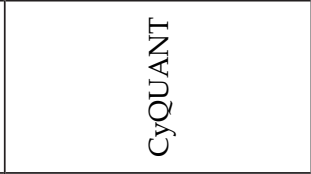 & & ' & 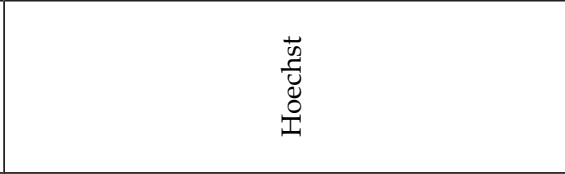 \\
\hline 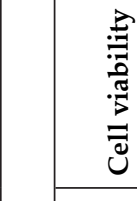 & 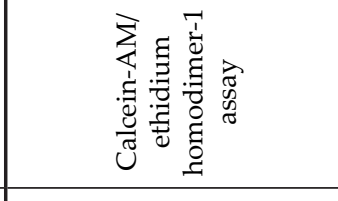 & 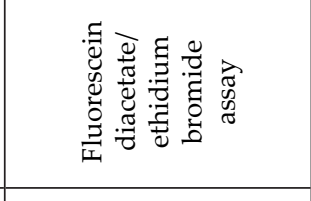 & 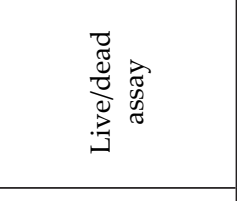 & 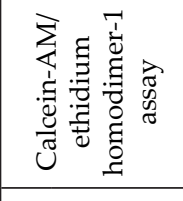 & \\
\hline 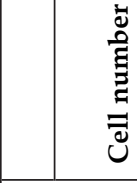 & 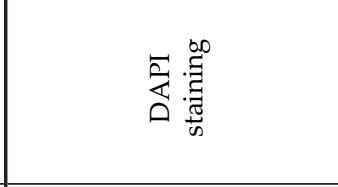 & & & ' & 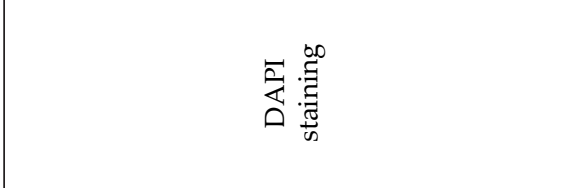 \\
\hline 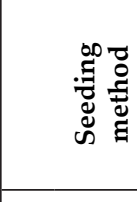 & 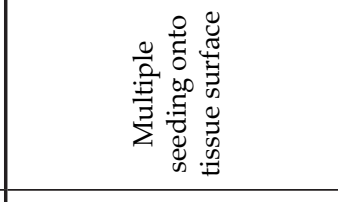 & 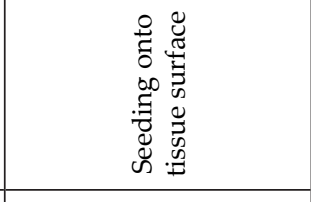 & 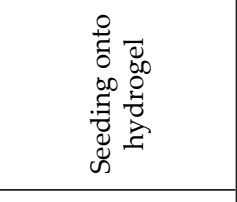 & 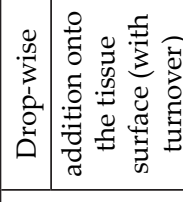 & 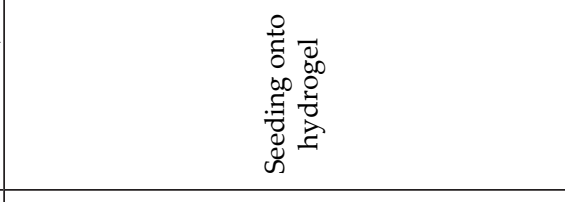 \\
\hline ฮี & 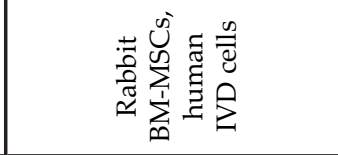 & 悉离 & 施 & 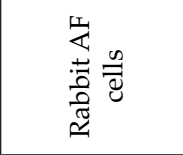 & 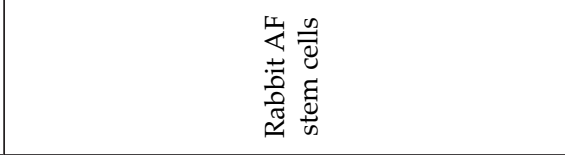 \\
\hline 竞: & 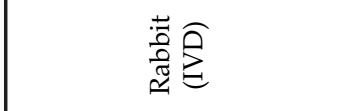 & 密 $\widehat{\underline{A}}$ & 喜死 & 莺要 & 蒙西 \\
\hline
\end{tabular}


$95 \%$ alcohol fumigation and ultraviolet irradiation to sterilise lyophilised decellularised AF tissues.

All in all, it is crucial to choose an adequate sterilisation method to maximise the properties and in vivo performance of biomaterials (Destefani et al., 2017).

\section{Recellularisation of decellularised IVD scaffolds}

After decellularisation, acellular scaffolds can be repopulated with specific cell sources to reconstitute a healthy ECM and enhance the regenerative process. Choosing the appropriate cell source for recellularisation is a complex issue that needs to be extensively studied.

Native IVD cells are widely used to recellularise IVD-based scaffolds, since they already present a chondrocyte-like phenotype and have shown positive outcomes (Chan et al., 2013; Ganey et al., 2003; Gruber et al., 2002). However, other cell types and different repopulation methods have been widely investigated. As summarised in Table 3, successful recellularisation of IVD scaffolds [either injectable (Illien-Junger et al., 2016; Lin et al., 2016; Peng et al., 2020; Wachs et al., 2017; Xu et al., 2019; Yu et al., 2020; Zhou et al., 2018) or not] has already been reported with bovine (Chan et al., 2013) and human (Illien-Junger et al., 2016; Wachs et al., 2017) NP cells as well as with rabbit (Liu et al., 2019) [either stem or not (Xu et al., 2014)] and human (Huang et al., 2016) AF cells.

At first glance, healthy human IVD cells seem to be the ideal cell source. Nevertheless, they represent only a small population in the disc and their isolation is a complex process due to ethical issues in using healthy young volunteers and a high risk of tissue disruption. Alternatively, IVD cells can be collected from patient's undergoing spinal surgeries. However, their degenerative phenotype can negatively impact the subsequent regenerative cascade in the context of a therapeutic approach. Nevertheless, IVD cells' behaviour will better mimic the response within a diseased microenvironment, being ideal for developing in vitro models of disc degeneration.

MSCs have started to be widely used because of their relatively ease of isolation and expansion, ability to differentiate into native disc-like cells, immunomodulatory properties and ability to produce their own ECM, inducing disc repair. MSCs are a more readily available option than IVD cells (Le Maitre et al., 2009; Lin et al., 2016; Wei et al., 2009; Zhou et al., 2018) and have started to be used in clinical trials to treat LBP (Kumar et al., 2017; Noriega et al., 2017). Moreover, MSCs have long-term self-renewal capability, are reservoirs of growth factors and cytokines and can contribute to the restoration of the disc matrix (Wang et al., 2015; Watanabe et al., 2010; Yang et al., 2008; Zhang et al., 2005). MSCs used for IVD regeneration studies are mainly bone-marrowor adipose-tissue-derived as they can be obtained through minimally invasive procedures (Huang et al.,
2016; Illien-Junger et al., 2016; Lin et al., 2016; Mercuri et al., 2011; Mercuri et al., 2013; Peng et al., 2020; Yu et al., 2020; Yuan et al., 2013; Zhou et al., 2018). However, stem cells from other sources such as amniotic fluid (Fernandez et al., 2016) or synovial tissue (Pei et al., 2012; Shoukry et al., 2013) also exhibit promising results. As previously discussed, it is important to choose the appropriate cell type for recellularisation but the use of autologous, allogenic or xenogenic cells must be carefully considered to reduce the chance of having scaffold rejection by the host.

Several methods have been investigated to achieve successful recellularisation of ECM-based scaffolds (Fig. 3). Seeding cell suspension over the biomaterial by simple dropping is the most used approach. However, cells tend to form a monolayer on the surface of dense scaffolds, rendering problematic their penetration and migration (Chan et al., 2013; Fernandez et al., 2016; Huang et al., 2016). Also, particular decellularisation detergents, such as SDS, affect GAG content of the native tissue, which leads to decreased water retention and consequently reduced cell adhesion to the matrix (Gilbert et al., 2006; Huang et al., 2016). Several techniques can be adopted to improve cell penetration and migration into the scaffolds, such as: rotatory cultures (Huang et al., 2016), scaffold turnover (Xu et al., 2014), repetitive cell seedings with $1 \mathrm{~h}$ intervals (Lin et al., 2016) and cell injection (Fernandez et al., 2016). Finally, cell repopulation can be enhanced by preincubating acellular scaffolds with FBS or BSA. These solutions can diminish the cytotoxicity caused by the decellularisation reagents. Particularly, Mercuri et al. (2011) immersed the decellularised scaffold in culture medium with serum (50\%), $24 \mathrm{~h}$ prior to cell seeding and observed a relative 2.4 -fold increase in cell number from $\sim 2.5 \times 10^{4}$ cells on day 3 to $\sim 6.1 \times 10^{4}$ cells on day 7 and cell migration into the scaffold after $7 \mathrm{~d}$ of culture. Nevertheless, with the same approach, Fernandez et al. (2016) did not observe cell migration within the scaffold. In another study, Schulze-Tanzil's group preconditioned the decellularised matrices in $5 \%$ BSA for $24 \mathrm{~h}$ and FBS for additional $24 \mathrm{~h}$. Although most of the seeded cells (either MSCs or IVD cells) survived, they only colonised the scaffold surface (Huang et al., 2016). It is important to consider that these differences may also reflect different cell sources or decellularisation methods used, since each particular approach can have a different impact on the physicochemical properties of the ECM, affecting cell adhesion and migration. After choosing the recellularisation method, it is also mandatory to determine the cell seeding density, which may depend on scaffold volume, cell type, culture duration and purpose of the experiment.

After reseeding, the success of the recellularisation procedure should be estimated. In most studies, the authors evaluate cell number, proliferation, cell viability, DNA and water content, tissue organisation, GAG and collagen composition. This information 
is also reviewed in Table 2. Overall, recellularised scaffolds are a valuable tool that can be optimised and refined to develop innovative therapies for IVD degeneration. In the future, high-throughput proteomics or single-cell transcriptomics could help to maximise the understanding of all the dynamic biological processes and different cell populations involved in the process of IVD regeneration.

\section{Controlling the immune response against decellularised IVD matrices}

The main cause of implant failure is hyper immunoreactivity towards the graft or its degradation products. The most common antigens that trigger such an inflammatory response are DNA and Gal (Badylak and Gilbert, 2008; Cheng et al., 2014). Their elimination can extend xenograft survival. Non-self-antigen (from transplants, bacteria or viruses) recognition initiates an immune response mediated by MHC class I and II (Boccafoschi et al., 2017; Chen et al., 2017; Warrington et al., 2011).Therefore, controlling non-self acute and chronic immune response (through adjusting both pro- and anti-inflammatory cues) is crucial for a successful implantation (Boccafoschi et al., 2017). Optimisation of the decellularisation process is key to avoid dampening the bioactivity of native ECM while minimising residual immunological agents. This prevents disease transmission, reduces inflammation and immune response towards the scaffold, decreasing rejection after implantation (Badylak et al., 2011; Cheng et al., 2014). Given that ECM proteins are among the most conserved proteins in evolution, with high levels of sequence homology, decellularisation should be enough for explants to be well tolerated (Hutter et al., 2000; Moroni and Mirabella, 2014; Ozbek et al., 2010; van der Rest and Garrone, 1991). In fact, due to being considered antiimmunogenic, decellularised matrices have been proposed not only for autografts (within the same individual) and allografts (from one individual to another of the same species with a different genotype) but also for xenografts (from another species) (Boccafoschi et al., 2017). Although dense matrices hinder complete cell removal, most commercially available decellularised materials do contain DNA traces without compromising their clinical efficacy (Cheng et al., 2014; Derwin et al., 2006; Gilbert et al., 2009; Zheng et al., 2005), thus, demonstrating that the DNA remnants may exist below a threshold that triggers a harsh immune response (Badylak and Gilbert, 2008; Cheng et al., 2014). Gal epitopes are usually found in most species but not in humans.

\section{Recellularisation methods}

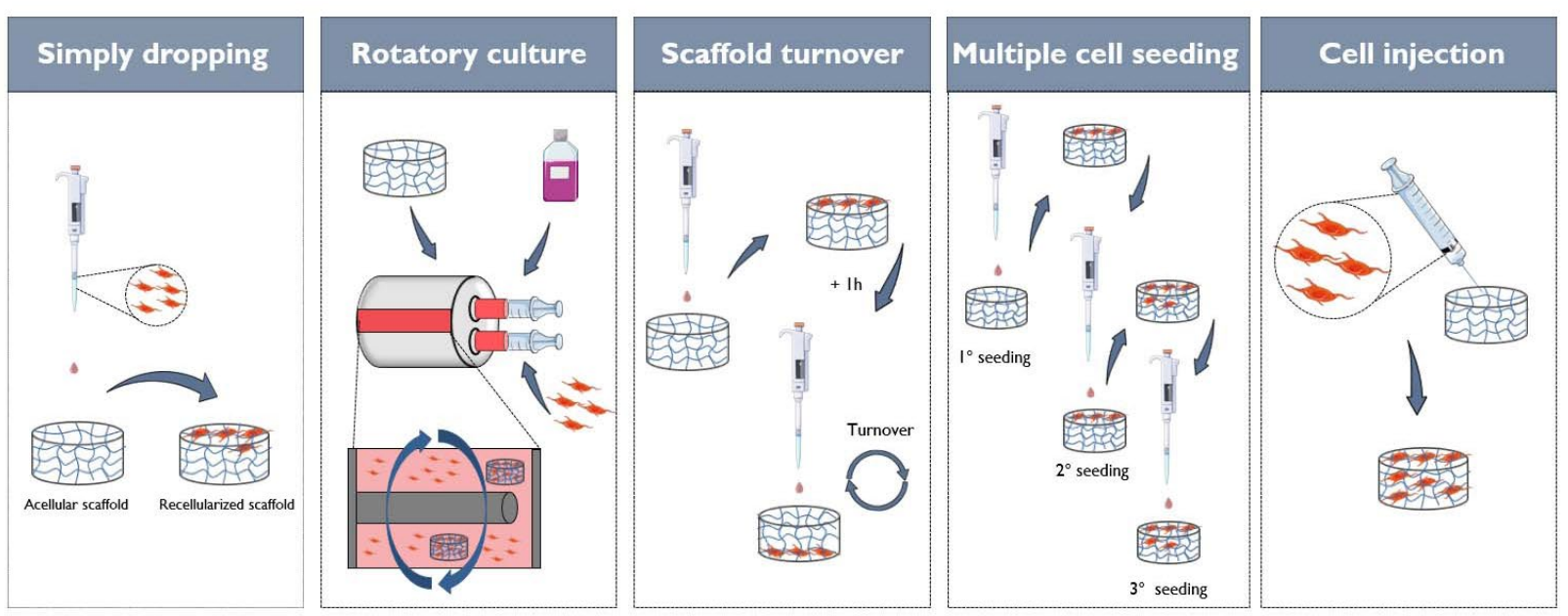

Cell migration reinforcement

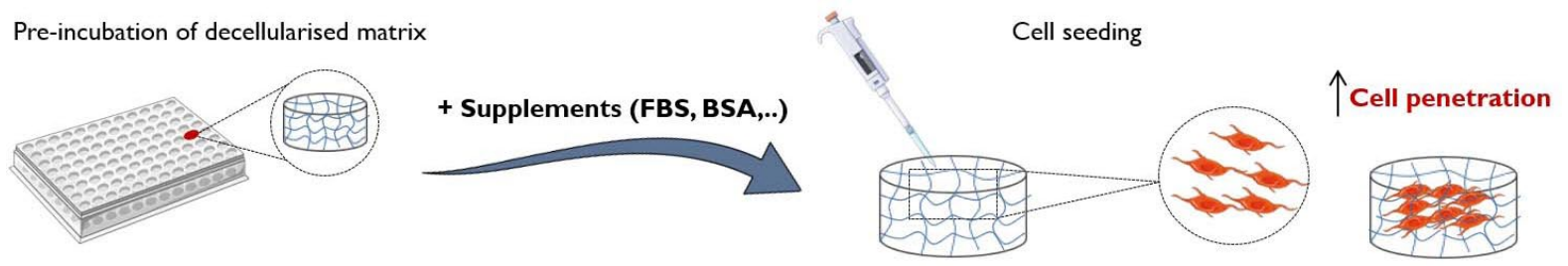

Fig. 3. Scaffold repopulation strategies. IVD scaffold repopulation, either with IVD cells or MSCs from different origins can be performed by drop-wise addition onto the surface of the decellularised scaffold. To improve recellularisation efficiency other strategies can be used such as mechanical agitation, scaffold turnover, multiple seedings or cell injection into the scaffold. To further promote cell penetration, decellularised matrices can be pre-incubated with protein-rich solutions such as FBS or BSA. 
Because humans are constantly exposed to intestinal bacteria that carry Gal epitopes, they produce large amounts of anti-Gal antibodies (Badylak and Gilbert, 2008; Cheng et al., 2014). In that context, porcine bioprosthetic heart valves have shown to induce a xenograft-specific immune response with high levels of cytotoxic IgM antibodies against a-Gal and have failed in some patients (Cheng et al., 2014; Konakci et al., 2005). Although organs from Gal-knockout pigs have been rejected due to other antigens (Chen et al., 2005), graft treatment with a-galactosidase has been able to remove Gal epitopes, minimising an adverse host immune reaction (Cheng et al., 2014; Stone et al., 2007; Stone et al., 1998). Research is still limited and further studies are needed to improve the safety and efficacy of decellularised material (Cheng et al., 2014).

In the disc field, only two works describe a-Gal assessment after decellularisation and in both cases there seems to be a removal (Mercuri et al., 2011) or at least a significant reduction of the a-Gal epitope in the decellularised scaffolds (native AFs: less than $10 \mathrm{ng} / \mathrm{mL}$; decellularised AFs: less than $5 \mathrm{ng} / \mathrm{mL}$ ) (Wu et al., 2017). Even if a residual amount remains, it evokes minimal to no immune response in vivo (Lin et al., 2016). Finally, it should be borne in mind that ECM fragments that result from degradation can also trigger inflammation (Molinos et al., 2015). This issue has not been given due consideration in most reports. Mechanisms responsible for macrophage switch from an M1 to an M2 profile should also be further studied in vivo to promote tissue remodelling and consequently improve scaffold biocompatibility (Moroni and Mirabella, 2014).

\section{In vivo behaviour of decellularised ECMs}

Biocompatibility of ECM-based scaffolds cannot be addressed only by using in vitro tests since they lack the complex biology and physiology of a whole organism. For that, in vivo assessments are needed to evaluate host responses to the scaffolds (Aamodt and Grainger, 2016). Mercuri et al. (2011) evaluated biocompatibility of the porcine-derived material in a rat model (subdermal pockets). Most non-crosslinked NP decellularised scaffolds were degraded completely after 4 weeks whereas crosslinking delayed degradation. In all the cases an inflammatory response was observed. Since DNA was removed in their previous work (Mercuri et al., 2011), the authors hypothesised that this reaction may be triggered by a delayed degradation of the crosslinked material and a possible interaction between GAGs, present in the scaffold, and proinflammatory cytokines (Mercuri et al., 2013).

Lin et al. (2016) assessed immunological response to decellularised rabbit IVD-based scaffolds in vivo in a rabbit model, in comparison to native tissue grafts. Subcutaneous decellularised implants presented minimal signs of inflammation 1 month postimplantation, while native scaffolds presented high levels of cell infiltration, namely of neutrophils, blood vessel formation and additional signs of inflammation
(Lin et al., 2016). A similar effect was observed when the same model was used with decellularised porcine xenografts seeded with MSCs (Xu et al., 2019).

Yuetal. (2020) evaluated the in vivo biocompatibility of a bovine NP hydrogel compared to a synthetic material (poly- $\varepsilon$-caprolactone) by subcutaneous implantation in a rat model. Following 2 and 4 weeks of NP hydrogel implantation, H\&E staining showed a smaller neutrophil and giant cell number, evidencing mild inflammation and reduced foreign body reaction in vivo (Yu et al., 2020). Also, the immunocompatibility of porcine decellularised AF scaffolds has been under studied. Using Wistar rats (box incision in rat tail), the authors have shown cell infiltration and tissue remodelling in the implanted animals, as evidenced by an increase in collagen and GAG content (Wu et al., 2017). More recently, Peng and colleagues have explored the ability of bovine AF-derived hydrogels to repair AF defects in vivo. They injected AF pre-hydrogel solutions, crosslinked or not with genipin (g-DAF-G and DAF-G, respectively), that were able to form a hydrogel in situ and to fill in AF defects. Moreover, both hydrogels induced disc cell migration and ECM production, demonstrating their regenerative potential in vivo (Peng et al., 2020).

Although most works did not observe cytotoxicity in vitro (except as a response to material crosslinking) (Borem et al., 2017; Fernandez et al., 2016), in vivo cell recruitment and repopulation is required for biointegration of the decellularised matrix and should be given due consideration.

Experiments using human tissue will be the ultimate frontier before clinical trials. Human ex vivo organ cultures are already underway to serve other purposes (Gawri et al., 2011; Walter et al., 2014) and should be used not only to test the effect of decellularised tissue grafts but also to assess the host response, at least to some extent.

\section{Limitations/precautions of using decellularised matrices}

\section{Donor profile}

The development of successful ECM-based scaffolds depends on a wide range of factors that need to be considered before their use in the clinics. The selection of tissue donor profile, including animal source and age, for instance, can have a dramatic impact on the regenerative process. Concerning IVD source, on one hand, the use of human degenerated tissues can negatively influence tissue repair, leading to implantation failure. On the other hand, human cadaveric IVDs, although supposedly healthy, are scarce and difficult to obtain due to ethical restrictions. Therefore, animal tissues can be a good alternative to overcome this issue. Baboons would be ideal, as they are large and conduct forces through their spine similarly to humans to which they are closely related (Lauerman et al., 1992). However, they are also limited in number, raise ethical concerns and 
constitute a potential source of zoonoses (Mafuyai et al., 2013). Porcine tissues are also good candidates and are already available on the market, as replacement heart valves and for wound management solutions (Tsuchiya et al., 2014). Bovine discs are large, easily available, have a similar NP aspect ratio and an identical ECM composition (Alini et al., 2008; Demers et al., 2004; O’Connell et al., 2007; Oshima et al., 1993; Roberts et al., 2008).

The donor age can also affect biomechanical properties and composition of ECM-based scaffolds (Cramer and Badylak, 2019). With ageing, native ECM undergoes several biochemical and structural changes, which can influence cell response and tissue remodelling when using biomaterials derived from these tissues (Cramer and Badylak, 2019).

Neonatal-derived scaffolds have an enhanced pro-regenerative potential, as already reported in the heart, abdominal wall muscle and kidney (Nakayama et al., 2011; Sicari et al., 2012; Silva et al., 2016). In the disc field, pro-regenerative proteins (collagen type XII and XIV) are uniquely expressed in prenatal IVD microenvironments (Caldeira et al., 2017). Moreover, foetal discs are also characterised by a different topography, when compared to young and adult tissues (Caldeira et al., 2018). Other age-associated structural differences of bovine discs can be observed in Fig. 1.

\section{Legislative issues}

Tissue engineering derivatives do not fall into the classification of drugs, transplants nor artificial tissues. As reviewed elsewhere (Boccafoschi et al., 2017), both the FDA and the European Commission proposed guidelines with a unified approach to regulate tissue-engineering products. Likewise, safety issues regarding xenotransplantation of cells and tissues should also be addressed. Characterisation of animal source, facilities and maintenance as well as of xenotransplantation products, selection of adequate preclinical models and recipient monitoring should be considered, as documented by the FDA and the European Union (Boccafoschi et al., 2017).

\section{Conclusions and future challenges}

The present review summarised the latest advances in IVD decellularisation. Recently, decellularised ECMbased scaffolds have gained significant attention for tissue remodelling with a regenerative purpose, given the success in cell removal and maintenance of most ECM properties with biological implications. Significant progress has been achieved in the last decade due to several exhaustive studies using a panoply of methods either alone or in combination, a wide range of reagents, several cell types and distinct animal sources. But there is still room for improvement, for instance by reducing treatment time and using milder detergents. Although recent progress is encouraging, several aspects need to be considered before commercialisation and clinical application, such as the following.

- Absence of a standardised protocol for decellularisation and for evaluating its efficacy, which renders the comparison of methods difficult. The ideal protocol should be scalable and effective, independent of donor species, age or pathological condition, and a final scaffold sterilisation step must be contemplated.

- Lack of uniformity of the optimal cell type, cell seeding density and cell repopulation method required for effective recellularisation. Appropriate selection of cell source will certainly determine the success of the therapy in vivo. Moreover, given the dense nature of the disc, cell infiltration into decellularised disc matrices can be hindered. The use of dynamic conditions could improve cell migration towards the inner scaffolds or, in alternative, decellularised matrix-based hydrogels (with increased porosity) or powders incorporated in different gels could be used to increase uniform cell distribution.

- Donor age (of the animals selected for tissue decellularisation). Despite being an often-neglected aspect, IVD matrisome is profoundly affected by age (Caldeira et al., 2017; 2018). Therefore, novel solutions using foetal tissues that mimic a healthy pre-natal landscape should be pursued for IVD regeneration (Fiordalisi et al., 2020).

- Limited in vivo validation. To verify clinical potential, biocompatibility of decellularised IVDbased scaffolds should be pursued preferentially using chondrodystrophic dogs, given that small rodents maintain notochordal cells throughout adulthood and do not reproduce human-disc size nor loading (Daly et al., 2016; Novais et al., 2020).

In conclusion, decellularised ECM-based scaffolds have a great potential to be translated into clinical applications for IVD repair and regeneration. Still, many challenges need to be solved and clinical trials must be conducted before these scaffolds can be launched on the market. Natural biomaterials are already revolutionising the tissue engineering field and their use for IVD could bring a new hope for LBP treatments.

\section{Acknowledgments}

We would like to acknowledge Claúdia Machado for all the technical support on histology troubleshooting. We would like to acknowledge support by The FCT funds FCT/DL 57/2016/CP1360/CT0005-JC, PhD grant (PD/BD/135544/2018-MF). This work was also financed by QREN (Quadro de Referência Estratégica Nacional). The project (20-165) was also supported by a grant from the ON Foundation, Switzerland.

The authors declare no conflict of interest. 


\section{References}

Aamodt JM, Grainger DW (2016) Extracellular matrix-based biomaterial scaffolds and the host response. Biomaterials 86: 68-82.

Adams MA, Roughley PJ (2006) What is intervertebral disc degeneration, and what causes it? Spine (Phila Pa 1976) 31: 2151-2161.

Agmon G, Christman KL (2016) Controlling stem cell behavior with decellularized extracellular matrix scaffolds. Curr Opin Solid State Mater Sci 20: 193-201.

Alini M, Eisenstein SM, Ito K, Little C, Kettler AA, Masuda K, Melrose J, Ralphs J, Stokes I, Wilke HJ (2008) Are animal models useful for studying human disc disorders/degeneration? Eur Spine J 17: 2-19.

Anderson DG, Tannoury C (2005) Molecular pathogenic factors in symptomatic disc degeneration. Spine J 5: 260S-266S.

Badylak SF, Gilbert TW (2008) Immune response to biologic scaffold materials. Semin Immunol 20: 109-116.

Badylak SF, Taylor D, Uygun K (2011) Wholeorgan tissue engineering: decellularization and recellularization of three-dimensional matrix scaffolds. Annu Rev Biomed Eng 13: 27-53.

Boccafoschi F, Botta M, Fusaro L, Copes F, Ramella M, Cannas M (2017) Decellularized biological matrices: an interesting approach for cardiovascular tissue repair and regeneration. J Tissue Eng Regen Med 11: 1648-1657.

Borem R, Madeline A, Walters J, Mayo H, Gill S, Mercuri J (2017) Angle-ply biomaterial scaffold for annulus fibrosus repair replicates native tissue mechanical properties, restores spinal kinematics, and supports cell viability. Acta Biomater 58: 254-268.

Bydon M, De la Garza-Ramos R, Macki M, Baker A, Gokaslan AK, Bydon A (2014) Lumbar fusion versus nonoperative management for treatment of discogenic low back pain: a systematic review and meta-analysis of randomized controlled trials. J Spinal Disord Tech 27: 297-304.

Caldeira J, Santa C, Osorio H, Molinos M, Manadas B, Goncalves R, Barbosa M (2017) Matrisome profiling during intervertebral disc development and ageing. Sci Rep 7: 11629. DOI: 10.1038/s41598-017-11960-0.

Caldeira J, Sousa A, Sousa D, Barros D (2018) Extracellular matrix constitution and function for tissue regeneration and repair. In: Peptides and proteins as biomaterials for tissue regeneration and repair. Editors: Barbosa MA, Martins MCL. Elsevier Woodhead Publishing Series. pp: 29-72.

Campoccia D, Montanaro L, Arciola CR (2006) The significance of infection related to orthopedic devices and issues of antibiotic resistance. Biomaterials 27: 2331-2339.

Chan LK, Leung VY, Tam V, Lu WW, Sze KY, Cheung KM (2013) Decellularized bovine intervertebral disc as a natural scaffold for xenogenic cell studies. Acta Biomater 9: 5262-5272.

Chen G, Qian H, Starzl T, Sun H, Garcia B, Wang X, Wise Y, Liu Y, Xiang Y, Copeman L, Liu W, Jevnikar
A, Wall W, Cooper DK, Murase N, Dai Y, Wang W, Xiong Y, White DJ, Zhong R (2005) Acute rejection is associated with antibodies to non-Gal antigens in baboons using Gal-knockout pig kidneys. Nat Med 11: $1295-1298$.

Chen Y, Chen J, Zhang Z, Lou K, Zhang Q, Wang S, Ni J, Liu W, Fan S, Lin X (2017) Current advances in the development of natural meniscus scaffolds: innovative approaches to decellularization and recellularization. Cell Tissue Res 370: 41-52.

Cheng CW, Solorio LD, Alsberg E (2014) Decellularized tissue and cell-derived extracellular matrices as scaffolds for orthopaedic tissue engineering. Biotechnol Adv 32: 462-484.

Colombier P, Clouet J, Hamel O, Lescaudron L, Guicheux J (2014) The lumbar intervertebral disc: from embryonic development to degeneration. Joint Bone Spine 81: 125-129.

Cramer MC, Badylak SF (2019) Extracellular matrix-based biomaterials and their influence upon cell behavior. Ann Biomed Eng 48: 2132-2153.

Crapo PM, Gilbert TW, Badylak SF (2011) An overview of tissue and whole organ decellularization processes. Biomaterials 32: 3233-3243.

Cs-Szabo G, Ragasa-San Juan D, Turumella V, Masuda K, Thonar EJ, An HS (2002) Changes in mRNA and protein levels of proteoglycans of the anulus fibrosus and nucleus pulposus during intervertebral disc degeneration. Spine (Phila Pa 1976) 27: 2212-2219.

Dai Z, Ronholm J, Tian Y, Sethi B, Cao X (2016) Sterilization techniques for biodegradable scaffolds in tissue engineering applications. J Tissue Eng 7: 2041731416648810. DOI: 10.1177/2041731416648810.

Daly C, Ghosh P, Jenkin G, Oehme D, Goldschlager $\mathrm{T}$ (2016) A review of animal models of intervertebral disc degeneration: pathophysiology, regeneration, and translation to the clinic. Biomed Res Int 2016: 5952165. DOI: 10.1155/2016/5952165.

Demers CN, Antoniou J, Mwale F (2004) Value and limitations of using the bovine tail as a model for the human lumbar spine. Spine (Phila Pa 1976) 29: 2793-2799.

DeQuach JA, Mezzano V, Miglani A, Lange S, Keller GM, Sheikh F, Christman KL (2010) Simple and high yielding method for preparing tissue specific extracellular matrix coatings for cell culture. PLoS One 5: e13039. DOI: 10.1371/journal.pone.0013039.

Derwin KA, Baker AR, Spragg RK, Leigh DR, Iannotti JP (2006) Commercial extracellular matrix scaffolds for rotator cuff tendon repair. Biomechanical, biochemical, and cellular properties. J Bone Joint Surg Am 88: 2665-2672.

Destefani AC, Sirtoli GM, Nogueira BV (2017) Advances in the knowledge about kidney decellularization and repopulation. Front Bioeng Biotechnol 5: 34. DOI: 10.3389/fbioe.2017.00034.

Duance VC, Crean JK, Sims TJ, Avery N, Smith S, Menage J, Eisenstein SM, Roberts S (1998) Changes in collagen cross-linking in degenerative disc disease and scoliosis. Spine (Phila Pa 1976) 23: 2545-2551. 
Fernandez C, Marionneaux A, Gill S, Mercuri J (2016) Biomimetic nucleus pulposus scaffold created from bovine caudal intervertebral disc tissue utilizing an optimal decellularization procedure. J Biomed Mater Res A 104: 3093-3106.

Fidalgo C, Iop L, Sciro M, Harder M, Mavrilas D, Korossis S, Bagno A, Palù G, Aguiari P, Gerosa G (2018) A sterilization method for decellularized xenogeneic cardiovascular scaffolds. Acta Biomater 67: 282-294.

Fiordalisi M, Silva AJ, Barbosa M, Gonçalves R, Caldeira J (2020) Decellularized scaffolds for intervertebral disc regeneration. Trends Biotechnol 38: 947-951.

Galbusera F, van Rijsbergen M, Ito K, Huyghe JM, Brayda-Bruno M, Wilke HJ (2014) Ageing and degenerative changes of the intervertebral disc and their impact on spinal flexibility. Eur Spine J 23 Suppl 3: S324-332.

Ganey T, Libera J, Moos V, Alasevic O, Fritsch KG, Meisel HJ, Hutton WC (2003) Disc chondrocyte transplantation in a canine model: a treatment for degenerated or damaged intervertebral disc. Spine (Phila Pa 1976) 28: 2609-2620.

Gawri R, Mwale F, Ouellet J, Roughley PJ, Steffen T, Antoniou J, Haglund L (2011) Development of an organ culture system for long-term survival of the intact human intervertebral disc. Spine (Phila Pa 1976) 36: 1835-1842.

Gilbert TW, Freund JM, Badylak SF (2009) Quantification of DNA in biologic scaffold materials. J Surg Res 152: 135-139.

Gilbert TW, Sellaro TL, Badylak SF (2006) Decellularization of tissues and organs. Biomaterials 27: 3675-3683.

Gilpin A, Yang Y (2017) Decellularization strategies for regenerative medicine: from processing techniques to applications. Biomed Res Int 2017: 9831534. DOI: 10.1155/2017/9831534.

Gruber HE, Johnson TL, Leslie K, Ingram JA, Martin D, Hoelscher G, Banks D, Phieffer L, Coldham G, Hanley EN, Jr. (2002) Autologous intervertebral disc cell implantation: a model using Psammomys obesus, the sand rat. Spine (Phila Pa 1976) 27: 16261633.

Hensley A, Rames J, Casler V, Rood C, Walters J, Fernandez C, Gill S, Mercuri JJ (2018) Decellularization and characterization of a whole intervertebral disk xenograft scaffold. J Biomed Mater Res A 106: 24122423.

Hoshiba T, Lu H, Kawazoe N, Chen G (2010) Decellularized matrices for tissue engineering. Expert Opin Biol Ther 10: 1717-1728.

Huang Z, Kohl B, Kokozidou M, Arens S, SchulzeTanzil G (2016) Establishment of a cytocompatible cell-free intervertebral disc matrix for chondrogenesis with human bone marrow-derived mesenchymal stromal cells. Cells Tissues Organs 201: 354-365.

Hulmes DJS (2008) Collagen diversity, synthesis and assembly. In: Collagen: structure and mechanics.
Editor: Fratzl P. Springer US, Boston, MA, USA. pp: $15-47$.

Hussey GS, Dziki JL, Badylak SF (2018) Extracellular matrix-based materials for regenerative medicine. Nat Rev Mat 3: 159-173.

Hutter H, Vogel BE, Plenefisch JD, Norris CR, Proenca RB, Spieth J, Guo C, Mastwal S, Zhu X, Scheel J, Hedgecock EM (2000) Conservation and novelty in the evolution of cell adhesion and extracellular matrix genes. Science 287: 989-994.

Iatridis JC, MacLean JJ, O'Brien M, Stokes IA (2007) Measurements of proteoglycan and water content distribution in human lumbar intervertebral discs. Spine (Phila Pa 1976) 32: 1493-1497.

Illien-Junger S, Sedaghatpour DD, Laudier DM, Hecht AC, Qureshi SA, Iatridis JC (2016) Development of a bovine decellularized extracellular matrixbiomaterial for nucleus pulposus regeneration. J Orthop Res 34: 876-888.

Konakci KZ, Bohle B, Blumer R, Hoetzenecker W, Roth G, Moser B, Boltz-Nitulescu G, Gorlitzer M, Klepetko W, Wolner E, Ankersmit HJ (2005) AlphaGal on bioprostheses: xenograft immune response in cardiac surgery. Eur J Clin Invest 35: 17-23.

Kumar H, Ha DH, Lee EJ, Park JH, Shim JH, Ahn TK, Kim KT, Ropper AE, Sohn S, Kim CH, Thakor DK, Lee SH, Han IB (2017) Safety and tolerability of intradiscal implantation of combined autologous adipose-derived mesenchymal stem cells and hyaluronic acid in patients with chronic discogenic low back pain: 1-year follow-up of a phase I study. Stem Cell Res Ther 8: 262. DOI: 10.1186/s13287-0170710-3.

Lauerman WC, Platenberg RC, Cain JE, Deeney VF (1992) Age-related disk degeneration: preliminary report of a naturally occurring baboon model. J Spinal Disord 5: 170-174.

Le Maitre CL, Baird P, Freemont AJ, Hoyland JA (2009) An in vitro study investigating the survival and phenotype of mesenchymal stem cells following injection into nucleus pulposus tissue. Arthritis Res Ther 11: R20. DOI: 10.1186/ar2611.

Leckie SK, Bechara BP, Hartman RA, Sowa GA, Woods BI, Coelho JP, Witt WT, Dong QD, Bowman BW, Bell KM, Vo NV, Wang B, Kang JD (2012) Injection of AAV2-BMP2 and AAV2-TIMP1 into the nucleus pulposus slows the course of intervertebral disc degeneration in an in vivo rabbit model. Spine J 12: 7-20.

Lee JS, Shin J, Park HM, Kim YG, Kim BG, Oh JW, Cho SW (2014) Liver extracellular matrix providing dual functions of two-dimensional substrate coating and three-dimensional injectable hydrogel platform for liver tissue engineering. Biomacromolecules 15: 206-218.

León-López A, Morales-Peñaloza A, MartínezJuárez VM, Vargas-Torres A, Zeugolis DI, AguirreÁlvarez G (2019) Hydrolyzed collagen-sources and applications. Molecules 24: 4031. DOI: 10.3390/ molecules24224031. 
Li B, Webster TJ (2018) Bacteria antibiotic resistance: new challenges and opportunities for implant-associated orthopedic infections. J Orthop Res 36: 22-32.

Lin X, Fang X, Wang Q, Hu Z, Chen K, Shan Z, Chen S, Wang J, Mo J, Ma J, Xu W, Qin A, Fan S (2016) Decellularized allogeneic intervertebral disc: natural biomaterials for regenerating disc degeneration. Oncotarget 7: 12121-12136.

Liu C, Jin Z, Ge X, Zhang Y, Xu H (2019) Decellularized annulus fibrosus matrix/chitosan hydrogels for annulus fibrous tissue engineering. Tissue Eng Part A 25: 1605-1613.

Londono R, Badylak SF (2015) Biologic scaffolds for regenerative medicine: mechanisms of in vivo remodeling. Ann Biomed Eng 43: 577-592.

Mafuyai HB, Barshep Y, Audu BS, Kumbak D, Ojobe TO (2013) Baboons as potential reservoirs of zoonotic gastrointestinal parasite infections at Yankari National Park, Nigeria. Afr Health Sci 13: 252-254.

Martin MD, Boxell CM, Malone DG (2002) Pathophysiology of lumbar disc degeneration: a review of the literature. Neurosurg Focus 13: E1. DOI: 10.3171/foc.2002.13.2.2.

Masuda K, Imai Y, Okuma M, Muehleman C, Nakagawa K, Akeda K, Thonar E, Andersson G, An HS (2006) Osteogenic protein-1 injection into a degenerated disc induces the restoration of disc height and structural changes in the rabbit anular puncture model. Spine (Phila Pa 1976) 31: 742-754.

McGuire R, Borem R, Mercuri J (2017) The fabrication and characterization of a multi-laminate, angle-ply collagen patch for annulus fibrosus repair. J Tissue Eng Regen Med 11: 3488-3493.

Mercuri JJ, Gill SS, Simionescu DT (2011) Novel tissue-derived biomimetic scaffold for regenerating the human nucleus pulposus. J Biomed Mater Res A 96: 422-435.

Mercuri JJ, Patnaik S, Dion G, Gill SS, Liao J, Simionescu DT (2013) Regenerative potential of decellularized porcine nucleus pulposus hydrogel scaffolds: stem cell differentiation, matrix remodeling, and biocompatibility studies. Tissue Eng Part A 19: 952-966.

Molinos M, Almeida CR, Caldeira J, Cunha C, Goncalves RM, Barbosa MA (2015) Inflammation in intervertebral disc degeneration and regeneration. J R Soc Interface 12: 20150429. DOI: 10.1098/ rsif.2015.0429.

Moroni F, Mirabella T (2014) Decellularized matrices for cardiovascular tissue engineering. Am J Stem Cells 3: 1-20.

Mwale F, Roughley P, Antoniou J (2004) Distinction between the extracellular matrix of the nucleus pulposus and hyaline cartilage: a requisite for tissue engineering of intervertebral disc. Eur Cell Mater 8: 58-63.

Nakayama KH, Batchelder CA, Lee CI, Tarantal AF (2011) Renal tissue engineering with decellularized rhesus monkey kidneys: age-related differences. Tissue Eng Part A 17: 2891-2901.

Nasser R, Yadla S, Maltenfort MG, Harrop JS, Anderson DG, Vaccaro AR, Sharan AD, Ratliff JK (2010) Complications in spine surgery. J Neurosurg Spine 13: 144-157.

Newell N, Little JP, Christou A, Adams MA, Adam CJ, Masouros SD (2017) Biomechanics of the human intervertebral disc: a review of testing techniques and results. J Mech Behav Biomed Mater 69: 420-434.

Noriega DC, Ardura F, Hernández-Ramajo R, Martín-Ferrero M, Sánchez-Lite I, Toribio B, Alberca M, García V, Moraleda JM, Sánchez A, García-Sancho J (2017) Intervertebral disc repair by allogeneic mesenchymal bone marrow cells: a randomized controlled trial. Transplantation 101: 1945-1951.

Novais EJ, Tran VA, Miao J, Slaver K, Sinensky A, Dyment NA, Addya S, Szeri F, van de Wetering K, Shapiro IM, Risbud MV (2020) Comparison of inbred mouse strains shows diverse phenotypic outcomes of intervertebral disc aging. Aging Cell 19: e13148. DOI: 10.1111/acel.13148.

Novotna Z, Reznickova A, Rimpelova S, Vesely M, Kolska Z, Svorcik V (2015) Tailoring of PEEK bioactivity for improved cell interaction: plasma treatment in action. RSC Advances 5: 41428-41436.

O'Connell GD, Vresilovic EJ, Elliott DM (2007) Comparison of animals used in disc research to human lumbar disc geometry. Spine (Phila Pa 1976) 32: 328-333.

Oegema TR, Jr. (1993) Biochemistry of the intervertebral disc. Clin Sports Med 12: 419-439.

Okuma M, Mochida J, Nishimura K, Sakabe K, Seiki K (2000) Reinsertion of stimulated nucleus pulposus cells retards intervertebral disc degeneration: an in vitro and in vivo experimental study. J Orthop Res 18: 988-997.

Onesti ST (2004) Failed back syndrome. Neurologist 10: 259-264.

Orozco L, Soler R, Morera C, Alberca M, Sánchez A, García-Sancho J (2011) Intervertebral disc repair by autologous mesenchymal bone marrow cells: a pilot study. Transplantation 92: 822-828.

Oshima H, Ishihara H, Urban JP, Tsuji H (1993) The use of coccygeal discs to study intervertebral disc metabolism. J Orthop Res 11: 332-338.

Ozbek S, Balasubramanian PG, ChiquetEhrismann R, Tucker RP, Adams JC (2010) The evolution of extracellular matrix. Mol Biol Cell 21: 4300-4305.

Pei M, Shoukry M, LiJ, DaffnerSD, FranceJC, Emery SE (2012) Modulation of in vitro microenvironment facilitates synovium-derived stem cell-based nucleus pulposus tissue regeneration. Spine (Phila Pa 1976) 37: 1538-1547.

Peng Y, Huang D, Li J, Liu S, Qing X, Shao Z (2020) Genipin-crosslinked decellularized annulus fibrosus hydrogels induces tissue-specific differentiation of bone mesenchymal stem cells and intervertebral disc regeneration. J Tissue Eng Regen Med 14: 497-509. 
Poornejad N, Nielsen JJ, Morris RJ, Gassman JR, Reynolds PR, Roeder BL, Cook AD (2015) Comparison of four decontamination treatments on porcine renal decellularized extracellular matrix structure, composition, and support of renal tubular epithelium cells. J Biomater Appl 30: 1154-1167.

Raj PP (2008) Intervertebral disc: anatomyphysiology-pathophysiology-treatment. Pain Pract 8: 18-44.

Roberts S, Menage J, Sivan S, Urban JP (2008) Bovine explant model of degeneration of the intervertebral disc. BMC Musculoskelet Disord 9: 24. DOI: 10.1186/1471-2474-9-24.

Sakai D, Mochida J, Iwashina T, Watanabe T, Nakai T, Ando K, Hotta T (2005) Differentiation of mesenchymal stem cells transplanted to a rabbit degenerative disc model: potential and limitations for stem cell therapy in disc regeneration. Spine (Phila Pa 1976) 30: 2379-2387.

Saldin LT, Cramer MC, Velankar SS, White LJ, Badylak SF (2017) Extracellular matrix hydrogels from decellularized tissues: structure and function. Acta Biomater 49: 1-15.

Schimmel JJ, Poeschmann MS, Horsting PP, Schönfeld DH, van Limbeek J, Pavlov PW (2016) PEEK cages in lumbar fusion: mid-term clinical outcome and radiologic fusion. Clin Spine Surg 29: E252-258.

Schizas C, Kulik G, Kosmopoulos V (2010) Disc degeneration: current surgical options. Eur Cell Mater 20: 306-315.

Shoukry M, Li J, Pei M (2013) Reconstruction of an in vitro niche for the transition from intervertebral disc development to nucleus pulposus regeneration. Stem Cells Dev 22: 1162-1176.

Sicari BM, Johnson SA, Siu BF, Crapo PM, Daly KA, Jiang H, Medberry CJ, Tottey S, Turner NJ, Badylak SF (2012) The effect of source animal age upon the in vivo remodeling characteristics of an extracellular matrix scaffold. Biomaterials 33: 55245533.

Silva AC, Rodrigues SC, Caldeira J, Nunes AM, Sampaio-Pinto V, Resende TP, Oliveira MJ, Barbosa MA, Thorsteinsdottir S, Nascimento DS, Pinto-do OP (2016) Three-dimensional scaffolds of fetal decellularized hearts exhibit enhanced potential to support cardiac cells in comparison to the adult. Biomaterials 104: 52-64.

Spang MT, Christman KL (2018) Extracellular matrix hydrogel therapies: in vivo applications and development. Acta Biomater 68: 1-14.

Stone KR, Abdel-Motal UM, Walgenbach AW, Turek TJ, Galili U (2007) Replacement of human anterior cruciate ligaments with pig ligaments: a model for anti-non-gal antibody response in longterm xenotransplantation. Transplantation 83: 211219.

Stone KR, Ayala G, Goldstein J, Hurst R, Walgenbach A, Galili U (1998) Porcine cartilage transplants in the cynomolgus monkey. III. Transplantation of alpha-galactosidase-treated porcine cartilage. Transplantation 65: 1577-1583.
Swann MC, Hoes KS, Aoun SG, McDonagh DL (2016) Postoperative complications of spine surgery. Best Pract Res Clin Anaesthesiol 30: 103-120.

Swartz KR, Trost GR (2003) Recurrent lumbar disc herniation. Neurosurg Focus 15: E10. DOI: 10.3171/ foc.2003.15.3.10.

Takaishi H, Nemoto O, Shiota M, Kikuchi T, Yamada H, Yamagishi M, Yabe Y (1997) Type-II collagen gene expression is transiently upregulated in experimentally induced degeneration of rabbit intervertebral disc. J Orthop Res 15: 528-538.

Tapias LF, Ott HC (2014) Decellularized scaffolds as a platform for bioengineered organs. Curr Opin Organ Transplant 19: 145-152.

Tomaszewski KA, Saganiak K, Gladysz T, Walocha JA (2015) The biology behind the human intervertebral disc and its endplates. Folia Morphol (Warsz) 74: 157-168.

Tsuchiya T, Sivarapatna A, Rocco K, Nanashima A, Nagayasu T, Niklason LE (2014) Future prospects for tissue engineered lung transplantation: decellularization and recellularization-based whole lung regeneration. Organogenesis 10: 196-207.

Urban JP, Roberts S (2003) Degeneration of the intervertebral disc. Arthritis Res Ther 5: 120-130.

Vadalà G, Sowa G, Hubert M, Gilbertson LG, Denaro V, Kang JD (2012) Mesenchymal stem cells injection in degenerated intervertebral disc: cell leakage may induce osteophyte formation. J Tissue Eng Regen Med 6: 348-355.

van der Rest M, Garrone R (1991) Collagen family of proteins. FASEB J 5: 2814-2823.

van Uden S, Silva-Correia J, Oliveira JM, Reis RL (2017) Current strategies for treatment of intervertebral disc degeneration: substitution and regeneration possibilities. Biomater Res 21: 22. DOI: 10.1186/s40824-017-0106-6.

Vernengo AJ, Grad S, Eglin D, Alini M, Li Z (2020) Bioprinting tissue analogues with decellularized extracellular matrix bioink for regeneration and tissue models of cartilage and intervertebral discs. Advanced Functional Materials 30: 1909044. DOI: 10.1002/adfm.201909044.

Veruva SY, Steinbeck MJ, Toth J, Alexander DD, Kurtz SM (2014) Which design and biomaterial factors affect clinical wear performance of total disc replacements? A systematic review. Clin Orthop Relat Res 472: 3759-3769.

Vos T, Flaxman AD, Naghavi M, Lozano R, Michaud C, Ezzati M, Shibuya K, Salomon JA, Abdalla S, Aboyans V, Abraham J, Ackerman I, Aggarwal R, Ahn SY, Ali MK, Alvarado M, Anderson HR, Anderson LM, Andrews KG, Atkinson C, Baddour LM, Bahalim AN, Barker-Collo S, Barrero LH, Bartels DH, Basanez MG, Baxter A, Bell ML, Benjamin EJ, Bennett D, Bernabe E, Bhalla K, Bhandari B, Bikbov B, Bin Abdulhak A, Birbeck G, Black JA, Blencowe H, Blore JD, Blyth F, Bolliger I, Bonaventure A, Boufous S, Bourne R, Boussinesq M, Braithwaite T, Brayne C, Bridgett L, Brooker S, Brooks P, Brugha TS, Bryan-Hancock C, Bucello C, Buchbinder R, Buckle G, 
Budke CM, Burch M, Burney P, Burstein R, Calabria B, Campbell B, Canter CE, Carabin H, Carapetis J, Carmona L, Cella C, Charlson F, Chen H, Cheng AT, Chou D, Chugh SS, Coffeng LE, Colan SD, Colquhoun S, Colson KE, Condon J, Connor MD, Cooper LT, Corriere M, Cortinovis M, de Vaccaro KC, Couser W, Cowie BC, Criqui MH, Cross M, Dabhadkar KC, Dahiya M, Dahodwala N, Damsere-Derry J, Danaei G, Davis A, De Leo D, Degenhardt L, Dellavalle R, Delossantos A, Denenberg J, Derrett S, Des Jarlais DC, Dharmaratne SD, Dherani M, Diaz-Torne C, Dolk H, Dorsey ER, Driscoll T, Duber H, Ebel B, Edmond K, Elbaz A, Ali SE, Erskine H, Erwin PJ, Espindola P, Ewoigbokhan SE, Farzadfar F, Feigin V, Felson DT, Ferrari A, Ferri CP, Fevre EM, Finucane MM, Flaxman S, Flood L, Foreman K, Forouzanfar $\mathrm{MH}$, Fowkes FG, Franklin R, Fransen M, Freeman MK, Gabbe BJ, Gabriel SE, Gakidou E, Ganatra HA, Garcia B, Gaspari F, Gillum RF, Gmel G, Gosselin R, Grainger R, Groeger J, Guillemin F, Gunnell D, Gupta R, Haagsma J, Hagan H, Halasa YA, Hall W, Haring D, Haro JM, Harrison JE, Havmoeller R, Hay RJ, Higashi H, Hill C, Hoen B, Hoffman H, Hotez PJ, Hoy D, Huang JJ, Ibeanusi SE, Jacobsen KH, James SL, Jarvis D, Jasrasaria R, Jayaraman S, Johns N, Jonas JB, Karthikeyan G, Kassebaum N, Kawakami N, Keren A, Khoo JP, King CH, Knowlton LM, Kobusingye O, Koranteng A, Krishnamurthi R, Lalloo R, Laslett LL, Lathlean T, Leasher JL, Lee YY, Leigh J, Lim SS, Limb E, Lin JK, Lipnick M, Lipshultz SE, Liu W, Loane M, Ohno SL, Lyons R, Ma J, Mabweijano J, MacIntyre MF, Malekzadeh R, Mallinger L, Manivannan S, Marcenes W, March L, Margolis DJ, Marks GB, Marks R, Matsumori A, Matzopoulos R, Mayosi BM, McAnulty JH, McDermott MM, McGill N, McGrath J, MedinaMora ME, Meltzer M, Mensah GA, Merriman TR, Meyer AC, Miglioli V, Miller M, Miller TR, Mitchell PB, Mocumbi AO, Moffitt TE, Mokdad AA, Monasta L, Montico M, Moradi-Lakeh M, Moran A, Morawska L, Mori R, Murdoch ME, Mwaniki MK, Naidoo K, Nair MN, Naldi L, Narayan KM, Nelson PK, Nelson RG, Nevitt MC, Newton CR, Nolte S, Norman P, Norman R, O'Donnell M, O'Hanlon S, Olives C, Omer SB, Ortblad K, Osborne R, Ozgediz D, Page A, Pahari B, Pandian JD, Rivero AP, Patten SB, Pearce N, Padilla RP, Perez-Ruiz F, Perico N, Pesudovs K, Phillips D, Phillips MR, Pierce K, Pion S, Polanczyk GV, Polinder S, Pope CA, 3rd, Popova S, Porrini E, Pourmalek F, Prince M, Pullan RL, Ramaiah KD, Ranganathan D, Razavi H, Regan M, Rehm JT, Rein DB, Remuzzi G, Richardson K, Rivara FP, Roberts T, Robinson C, De Leon FR, Ronfani L, Room R, Rosenfeld LC, Rushton L, Sacco RL, Saha S, Sampson U, Sanchez-Riera L, Sanman E, Schwebel DC, Scott JG, Segui-Gomez M, Shahraz S, Shepard DS, Shin H, Shivakoti R, Singh D, Singh GM, Singh JA, Singleton J, Sleet DA, Sliwa K, Smith E, Smith JL, Stapelberg NJ, Steer A, Steiner T, Stolk WA, Stovner LJ, Sudfeld C, Syed S, Tamburlini G, Tavakkoli M, Taylor HR, Taylor JA, Taylor WJ, Thomas B, Thomson WM, Thurston GD, Tleyjeh IM, Tonelli M, Towbin JA, Truelsen T, Tsilimbaris MK,
Ubeda C, Undurraga EA, van der Werf MJ, van Os J, Vavilala MS, Venketasubramanian N, Wang M, Wang W, Watt K, Weatherall DJ, Weinstock MA, Weintraub R, Weisskopf MG, Weissman MM, White RA, Whiteford H, Wiersma ST, Wilkinson JD, Williams HC, Williams SR, Witt E, Wolfe F, Woolf AD, Wulf S, Yeh PH, Zaidi AK, Zheng ZJ, Zonies D, Lopez AD, Murray CJ, AlMazroa MA, Memish ZA (2012) Years lived with disability (YLDs) for 1160 sequelae of 289 diseases and injuries 1990-2010: a systematic analysis for the Global Burden of Disease Study 2010. Lancet 380: 2163-2196.

Wachs RA, Hoogenboezem EN, Huda HI, Xin S, Porvasnik SL, Schmidt CE (2017) Creation of an injectable in situ gelling native extracellular matrix for nucleus pulposus tissue engineering. Spine J 17: 435-444.

Waddell G (1996) Low back pain: a twentieth century health care enigma. Spine (Phila Pa 1976) 21: 2820-2825.

Walsh AJ, Bradford DS, Lotz JC (2004) In vivo growth factor treatment of degenerated intervertebral discs. Spine (Phila Pa 1976) 29: 156-163.

Walter BA, Illien-Junger S, Nasser PR, Hecht AC, Iatridis JC (2014) Development and validation of a bioreactor system for dynamic loading and mechanical characterization of whole human intervertebral discs in organ culture. J Biomech 47: 2095-2101.

Wang F, Shi R, Cai F, Wang YT, Wu XT (2015) Stem cell approaches to intervertebral disc regeneration: obstacles from the disc microenvironment. Stem Cells Dev 24: 2479-2495.

Warrington R, Watson W, Kim HL, Antonetti FR (2011) An introduction to immunology and immunopathology. Allergy Asthma Clin Immunol 7 Suppl 1: S1. DOI: 10.1186/1710-1492-7-S1-S1.

Watanabe T, Sakai D, Yamamoto Y, Iwashina T, Serigano K, Tamura F, Mochida J (2010) Human nucleus pulposus cells significantly enhanced biological properties in a coculture system with direct cell-to-cell contact with autologous mesenchymal stem cells. J Orthop Res 28: 623-630.

Wei A, Chung SA, Tao H, Brisby H, Lin Z, Shen B, Ma DD, Diwan AD (2009) Differentiation of rodent bone marrow mesenchymal stem cells into intervertebral disc-like cells following coculture with rat disc tissue. Tissue Eng Part A 15: 2581-2595.

Whatley B, Wen X (2012) Intervertebral disc (IVD): structure, degeneration, repair and regeneration. Mater Sci Eng C 32: 61-77.

White AA, Panjabi MM (1990) Clinical biomechanics of the spine. Lippincott Williams \& Wilkins, Philadelphia.

White LJ, Keane TJ, Smoulder A, Zhang L, Castleton AA, Reing JE, Turner NJ, Dearth CL, Badylak SF (2018) The impact of sterilization upon extracellular matrix hydrogel structure and function. J Immunol Regen Med 2: 11-20.

White LJ, Taylor AJ, Faulk DM, Keane TJ, Saldin LT, Reing JE, Swinehart IT, Turner NJ, Ratner BD, 
Badylak SF (2017) The impact of detergents on the tissue decellularization process: A ToF-SIMS study. Acta Biomater 50: 207-219.

Wu LC, Chiang CJ, Liu ZH, Tsuang YH, Sun JS, Huang YY (2014) Fabrication and properties of acellular porcine anulus fibrosus for tissue engineering in spine surgery. J Orthop Surg Res 9: 118. DOI: 10.1186/s13018-014-0118-z.

Wu LC, Kuo YJ, Sun FW, Chen CH, Chiang CJ, Weng PW, Tsuang YH, Huang YY (2017) Optimized decellularization protocol including alpha-Gal epitope reduction for fabrication of an acellular porcine annulus fibrosus scaffold. Cell Tissue Bank 18: 383-396.

Xu H, Xu B, Yang Q, Li X, Ma X, Xia Q, Zhang Y, Zhang C, Wu Y, Zhang Y (2014) Comparison of decellularization protocols for preparing a decellularized porcine annulus fibrosus scaffold. PLoS One 9: e86723. DOI: 10.1371/journal.pone.0086723.

Xu J, Liu S, Wang S, Qiu P, Chen P, Lin X, Fang X (2019) Decellularised nucleus pulposus as a potential biologic scaffold for disc tissue engineering. Mater Sci Eng C Mater Biol Appl 99: 1213-1225.

Yang SH, Wu CC, Shih TT, Sun YH, Lin FH (2008) In vitro study on interaction between human nucleus pulposus cells and mesenchymal stem cells through paracrine stimulation. Spine (Phila Pa 1976) 33: 19511957.

Yu L, Sun ZJ, Tan QC, Wang S, Wang WH, Yang XQ, Ye XJ (2020) Thermosensitive injectable decellularized nucleus pulposus hydrogel as an ideal biomaterial for nucleus pulposus regeneration. J Biomater Appl 35: 182-192.

Yuan M, Pai PJ, Liu X, Lam H, Chan BP (2018) Proteomic analysis of nucleus pulposus cell-derived extracellular matrix niche and its effect on phenotypic alteration of dermal fibroblasts. Sci Rep 8: 1512. DOI: 10.1038/s41598-018-19931-9.

Yuan M, Yeung CW, Li YY, Diao H, Cheung KM, Chan D, Cheah K, Chan PB (2013) Effects of nucleus pulposus cell-derived acellular matrix on the differentiation of mesenchymal stem cells. Biomaterials 34: 3948-3961.

Yue B, Lin Y, Ma X, Xiang H, Qiu C, Zhang J, Li L, Chen B (2016) Survivin-TGFB3-TIMP1 gene therapy via lentivirus vector slows the course of intervertebral disc degeneration in an in vivo rabbit model. Spine (Phila Pa 1976) 41: 926-934.

Zhang YG, Guo X, Xu P, Kang LL, Li J (2005) Bone mesenchymal stem cells transplanted into rabbit intervertebral discs can increase proteoglycans. Clin Orthop Relat Res: 219-226. DOI: 10.1097/01. blo.0000146534.31120.cf.

Zheng MH, Chen J, Kirilak Y, Willers C, Xu J, Wood D (2005) Porcine small intestine submucosa (SIS) is not an acellular collagenous matrix and contains porcine DNA: possible implications in human implantation. J Biomed Mater Res B Appl Biomater 73: 61-67.

Zhou X, Wang J, Huang X, Fang W, Tao Y, Zhao T, Liang C, Hua J, Chen Q, Li F (2018) Injectable decellularized nucleus pulposus-based cell delivery system for differentiation of adipose-derived stem cells and nucleus pulposus regeneration. Acta Biomater 81: 115-128.

\section{Discussion with Reviewer}

Reviewer: Often, sterilisation methods impact the macromolecular structure of a biomaterial and, therefore, its performance. Have different sterilisation methods of decellularised ECM been characterised in terms of effects on bioactivity, mechanical and degradation properties? Do the authors anticipate any specific challenges, in sterilisation methods, that will need to be overcome for clinical translation of this technology?

Authors: Sterilisation of IVD-based scaffolds remains an underexplored field. Although different techniques have been under study to effectively remove any tissue contaminants, as described in the section "Sterilisation of decellularised IVD matrices", the authors of the revised works have not exhaustively investigated the impact of these methods on scaffold bioactivity, degradation, composition or biomechanics. As described for other tissue-derived matrices, most of the methods used for scaffolds sterilisation are disruptive and can affect ECM structure and biomechanical properties, which are essential for the success of tissue regeneration. Nowadays, there is no ideal option for effective and minimally destructive sterilisation, however research is advancing with significant progress. The major challenge that needs to be overcome in IVD sterilisation is the development of a less destructive method but at the same time efficient enough to face clinical requests. Recently, supercritical carbon dioxide sterilisation has started to emerge as a promising strategy for terminal sterilisation, with no signs of negative effects regarding biomaterial composition (molecular weight, components content) and properties (biological, mechanical and physicochemical) (Ribeiro et al., 2020, additional reference). In the future, this technology should be further explored for tissue sterilisation, including the IVD.

\section{Additional Reference}

Ribeiro N, Soares GC, Santos-Rosales V, Concheiro A, Alvarez-Lorenzo C, García-González CA, Oliveira AL (2020) A new era for sterilization based on supercritical CO2 technology. J Biomed Mater Res B Appl Biomater 108: 399-428.

Editor's note: The Guest Editor responsible for this paper was Zhen Li. 